\title{
Bonamia ostreae-induced mortalities in one-year old European flat oysters Ostrea edulis: experimental infection by cohabitation challenge
}

\author{
Delphine Lallias ${ }^{1,2, a}$, Isabelle Arzul ${ }^{1}$, Serge Heurtebise ${ }^{1}$, Sylvie Ferrand ${ }^{1}$, Bruno Chollet $^{1}$, Maeva Robert ${ }^{1}$, \\ Andy R. Beaumont ${ }^{2}$, Pierre Boudry ${ }^{1, b}$, Benjamin Morga ${ }^{1}$ and Sylvie Lapègue ${ }^{1}$ \\ ${ }^{1}$ IFREMER, Laboratoire Génétique et Pathologie, Ronce-les-bains, 17390 La Tremblade, France \\ 2 School of Ocean Sciences, College of Natural Sciences, Bangor University, Menai Bridge, Anglesey, LL59 5AB, UK
}

Received 3 April 2008; Accepted 10 July 2008

\begin{abstract}
Bonamiosis is a parasitic disease (causative agent: Bonamia ostreae) affecting the European flat oyster Ostrea edulis, responsible for a drastic decline in its aquaculture production. Selective breeding programs for resistance to bonamiosis have been undertaken to counter this disease. In the present study, a 6-month cohabitation challenge experiment was performed in order to transmit the disease from wild oysters injected with the parasite to two tested families of oysters (20 and 8-month old at the beginning of the experiment, with different genetic backgrounds) originating from a selective breeding program developed by IFREMER in France. Mortalities were checked daily and ventricular heart smears were performed on dying or moribund oysters to detect the level of infection by B. ostreae. Mortality started after 4 months of cohabitation in the tested oysters. The cumulative mortalities after 6 months were $58 \%$ for the wild oysters, $9 \%$ for Family 1 (20-month old) and $20 \%$ for Family 2 (8-month old). In the dying oysters, the parasite could be detected in $67 \%$ of the wild oysters, $68 \%$ of Family 1 and $89 \%$ of Family 2 . It was detected in only $11 \%$ of the surviving oysters of Family 2 . The mortality and the level of infection by the parasite were significantly higher in Family 2 than in Family 1. Our results demonstrate that prespawning oysters as young as 1 year-old can become infected with the parasite and, most importantly, can die from bonamiosis. This result is inconsistent with the commonly accepted critical age of 2 years-old for the disease development. Additionally, no clear relationship between shell length and level of infection was observed. We also review the different methods for infection of the European flat oyster O. edulis with B. ostreae under experimental conditions and their main results.
\end{abstract}

Key words: Ostrea edulis / Bonamia ostreae / Cohabitation experiment / Transmission / Heart smear

Résumé - Mortalités induites par Bonamia ostreae chez des huîtres plates européennes Ostrea edulis âgées d'un an : infection expérimentale par cohabitation. La bonamiose est une maladie parasitaire (agent causal : Bonamia ostreae) affectant l'huître plate européenne Ostrea edulis, responsable d'un déclin drastique de sa production aquacole. Des programmes de sélection pour la résistance à la bonamiose ont été entrepris pour contrer cette maladie. Dans cette étude, une expérience de 6 mois d'infection par cohabitation a été réalisée de manière à transmettre la maladie à partir d'huîtres sauvages injectées avec le parasite vers deux familles testées d'huîtres (âgées de 20 et 8 mois en début d'expérience, avec des origines génétiques différentes) issues du programme de sélection développé par IFREMER en France. Les mortalités ont été vérifiées quotidiennement et des frottis de cœur ventriculaire réalisés sur les huîtres mortes ou moribondes pour détecter le niveau d'infection par B. ostreae. La mortalité a commencé chez les huîtres testées après 4 mois de cohabitation. Les mortalités cumulées après 6 mois étaient de $58 \%$ chez les huîtres sauvages, $9 \%$ chez la Famille 1 (âgées de 20 mois) et $20 \%$ chez la Famille 2 (âgées de 8 mois). Chez les huîtres mourantes, le parasite a pu être détecté chez $67 \%$ des huîtres sauvages, $68 \%$ de la Famille 1 et $89 \%$ de la Famille 2. Il n'a pu être détecté que chez $11 \%$ des huîtres survivantes de la Famille 2. La mortalité et le niveau d'infection par le parasite étaient significativement plus élevés chez la Famille 2 que chez la Famille 1. Nos résultats démontrent que des huîtres âgées de un an peuvent devenir infectées par le parasite et surtout, peuvent mourir de bonamiose. Ce résultat

\footnotetext{
${ }^{\text {a } C o r r e s p o n d i n g ~ a u t h o r: ~ d . l a l l i a s @ b a n g o r . a c . u k ~}$

b Present address: IFREMER, UMR M100 Physiologie et Ecophysiologie des Mollusques marins, BP 70, 29280 Plouzané, France
} 
contraste avec l'âge critique de développement de la maladie communément accepté de 2 ans. De plus, aucune relation claire entre la longueur de la coquille et le niveau d'infection n'a été observée. Nous faisons également la revue des différentes méthodes d'infection de l'huître plate européenne $O$. edulis avec B. ostreae en conditions expérimentales et leurs principaux résultats.

\section{Introduction}

The European flat oyster Ostrea edulis is a species endemic to European and North African coasts and can be found from Norway to Morocco as well as in the whole Mediterranean Basin (Jaziri 1985). It is a sequential protandrous hermaphroditic oyster which can change sex within one breeding season, being asynchronously male or female although selfing has been recorded under experimental conditions (Lallias 2007) and which broods eggs and early larvae in the mantle cavity of the female (Yonge 1960; Le Dantec and Marteil 1976).

Following overexploitation of European oyster populations during the $19^{\text {th }}$ century, massive mortalities occurred in France in the 1920's. Some populations later recovered but many were replaced by the Portuguese oyster Crassostrea angulata that had been introduced accidentally into France in the 1860's and later by the Pacific oyster Crassostrea gigas in 1970's (Comps and Duthoit 1976). Over the last forty years, European production of $O$. edulis has shown a drastic decline from a peak output of nearly 30000 tons in 1961, mainly due to the rapid spread and strong impact of two parasitic diseases, due to Marteilia refringens and Bonamia ostreae. In 2006, 61\% of the production was in Spain (3200 tons) and 19\% in France (1000 tons) (FAO 2007).

Bonamiosis is an intrahaemocytic parasitosis caused by the protozoans Bonamia ostreae and Bonamia exitiosa. The parasite B. ostreae was first described in Brittany (France) by Pichot et al. (1979) and Comps et al. (1980). It is an intracellular parasite $(2-5 \mu \mathrm{m})$ that infects haemocytes and exhibits two distinct cellular types, either dense or clear cells. Its inclusion into the phylum Haplosporidia has recently been confirmed (Carnegie et al. 2000; Cochennec et al. 2000). This disease was later reported in the Netherlands (Van Banning 1985, 1991), Denmark (Elston et al. 1987), Spain (Montes and Melendez 1987; Figueras 1991), England (Bucke et al. 1984), Ireland (McArdle et al. 1991) and North America (Elston et al. 1986; Friedman et al. 1989; Barber and Davis 1994; Friedman and Perkins 1994). The disease has been correlated with haemocyte destruction and haemocytic infiltration of the connective tissue of the gills, mantle and digestive gland due to the proliferation of B. ostreae (Balouet et al. 1983; Cochennec-Laureau et al. 2003). The first mortalities are generally observed when the oysters reach two-years old (Culloty and Mulcahy 1996) although younger individuals $(0+$ and $1+)$ have been shown to be susceptible to the infection (Lynch et al. 2005). Some studies reported a seasonal pattern of prevalence and mortality, with highest levels occurring in autumn-winter (Grizel 1985; Montes 1990; Van Banning 1991; Culloty and Mulcahy 1996).

Numerous studies have aimed to clarify the mode of transmission and dynamics of the disease (see Annexes 1 to 4). Most of them were based on field testing, deploying naïve oysters (i.e. never exposed to the parasite) in a contaminated area, recording the time to the first infections and their evolution over time (Poder et al. 1982; Tigé and Grizel 1984; Montes 1991; Martin et al. 1993; Cáceres-Martínez et al. 1995; Culloty and Mulcahy 1996; Naciri-Graven et al. 1998; Culloty et al. 1999; Montes et al. 2003; Culloty et al. 2004; Lynch et al. 2005). Other studies were based on experimental cohabitation between oysters sampled in contaminated areas and naïve oysters, in order to analyze the evolution of the disease (Elston et al. 1986, 1987; Martin et al. 1993; Culloty et al. 1999). The development of a protocol to purify $B$. ostreae from infected oysters (Mialhe et al. 1988) enabled experimental infections by injecting the parasite into flat oysters (Mialhe et al. 1988; Martin et al. 1993; Hervio et al. 1995; Culloty et al. 1999) or by the cohabitation between source oysters injected with a known number of cells of B. ostreae and naïve oysters (Culloty et al. 1999). Finally, several studies focused on the role of intermediate hosts or vectors in the transmission of the disease, in particular the role of the macrofauna (Culloty et al. 1999; Lynch et al. 2007).

Despite new management practices (e.g. reducing stocking densities under suspension culture or selling oysters at a lower weight before significant $B$. ostreae-induced mortalities occur), the production of $O$. edulis in Europe has remained low due to bonamiosis. Selective breeding programs were initiated in Ireland and France, with the main objective of producing flat oysters tolerant to bonamiosis (Culloty et al. 2004; Lapègue et al. 2004). In France, this was first initiated in 1985 by IFREMER, producing two oyster strains (S85 and S89) by mass spawning (Naciri-Graven et al. 1998). Individual selection was applied through inoculation tests and field testing, the surviving oysters being used to produce the next generation. Three generations of selection were carried out for S85 and two for S89. At that stage, microsatellite analyses showed that these strains exhibited a low genetic diversity due to population bottlenecks, leading to small effective population sizes and subsequent inbreeding (Launey et al. 2001). As a result, the second stage of this selective breeding program consisted of the production of bi-parental families combined with within-family selection. Families produced in 1995 consisted of within-strain crosses. Then, in order to maximize genetic variability, families produced in 1998 were issued from among-strain crosses between S85 and S89 (Launey 1998). These families showed enhanced survival and lower prevalence of the parasite compared with control wild-type oysters in B. ostreae-contaminated areas (Lapègue et al. 2004).

The aim of the present study was to undertake a challenge experiment by cohabitation in order to transmit the disease from wild oysters (injected with the parasite) to two families of oysters originating from the IFREMER selective breeding program and to follow the dynamics of mortality in association with the detection of $B$. ostreae. We also review the different methods for infection of the European flat oyster O. edulis with $B$. ostreae under experimental conditions and their main results. 


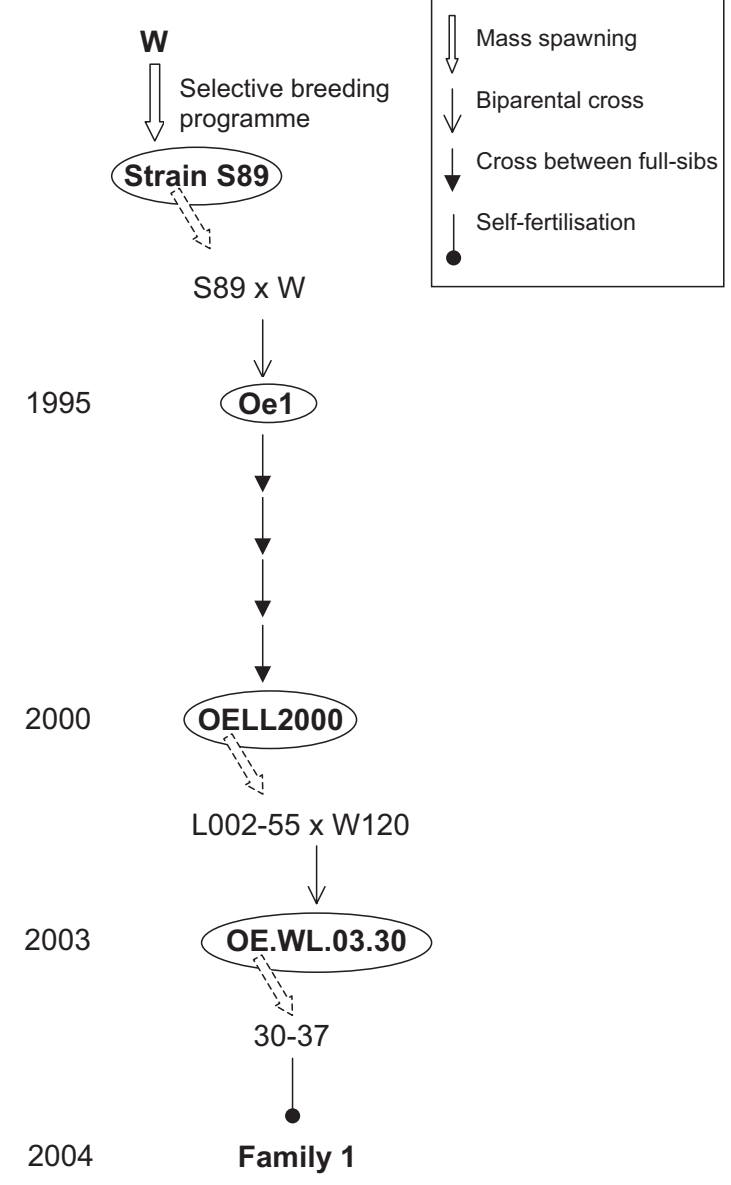

Fig. 1. Production of the experimental Family 1. W: wild oysters; S: selected strain; L: inbred line. OELL2000 is an inbred line of $4^{\text {th }}$ generation.

\section{Materials and methods}

\subsection{Wild oysters}

Wild oysters weighing 45-50 g $(n=462)$ were collected in January 2006 from Quiberon Bay (Brittany, France), a bonamiosis-infected zone since 1980. Prevalence reported in Quiberon Bay in October 2005 was estimated to be 4\% (data from REPAMO, French network for the surveillance of mollusc diseases).

\subsection{Biparental families}

Because flat oysters are alternating hermaphrodites and females brood their larvae in their mantle cavity, it was not possible to determine in advance the sex of the oysters or to strip spawn the gonads for collecting gametes. Therefore, all biparental crosses were achieved by putting pairs of oysters in 21 aquaria, each aquarium being individually supplied with filtered sea water. The outlet water pipe of each aquarium was placed above a $100 \mu \mathrm{m}$-mesh sieve for the collection of larvae. Sieves were checked daily for the presence of larvae and larvae and spat were cultured following a protocol based on that originally described by Walne (1974).

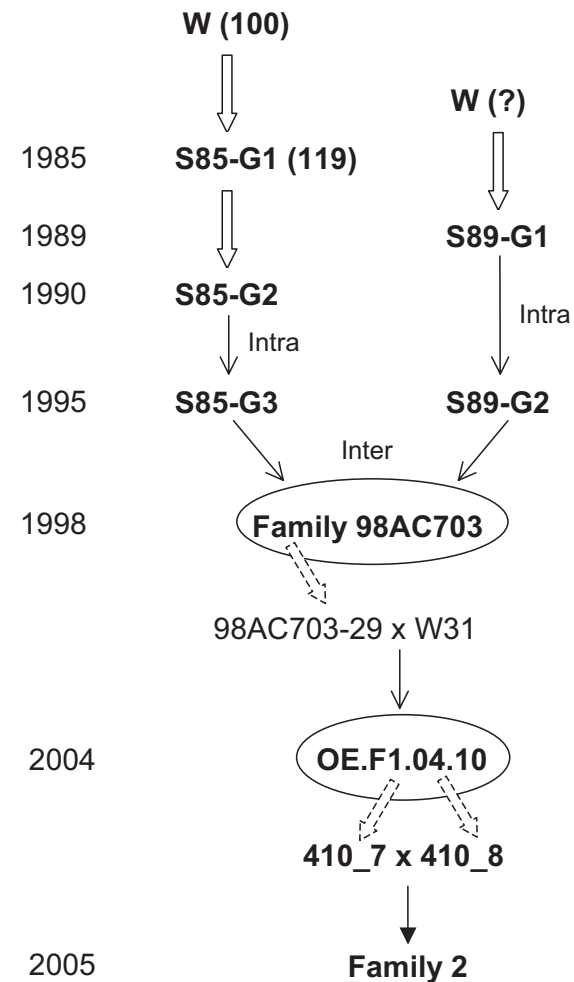

Fig. 2. Production of the experimental Family 2. W: wild oysters. In bracket is stated the number of progenitors used to produce the next generation by mass spawning ?: unknown number of progenitors. S85-G1, S85-G2 and S85-G3 represent the three generations of selection of the selected strain S85. S89-G1 and S89-G2 represent the two generations of selection of the selected strain S89. Intra: intra-strain biparental crosses; Inter: inter-strain biparental crosses.

The first experimental family, Family 1 (Fig. 1), was initiated in 2003 by crossing a wild-type oyster and an oyster from the inbred line OELL2000 to make an F1 family. This inbred line was derived from a cross between an oyster from the IFREMER selected strain S89 (see above) and a wild oyster, followed by 4 generations of biparental crosses between fullsibs. Two full-sibs from this F1 family ("30-37" and "30-38”) were then placed in an aquarium together in 2004 to obtain the F2 generation. However, microsatellite-based parentage analyses later revealed that all of the F2 offspring came from a self-fertilisation of the F1 parent 30-37 (Lallias 2007).

The second experimental family, Family 2 (Fig. 2), was initiated in 2004 by firstly crossing a wild oyster with an oyster from one of the selected families produced in 1998 during the selective breeding program to produce an F1 family. A secondgeneration was obtained in 2005 by crossing two full-sibs from this F1 family. Parentage was confirmed by microsatellite analysis (Lallias 2007).

Families 1 and 2 were 20 and 8-month old at the beginning of the experiment.

\subsection{Bonamia challenge experiment}

Our experimental design consisted of 10 raceways, 5 containing Family 1 with 100 oysters per raceway and 
5 containing Family 2 with 110 oysters per raceway. Each raceway contained 4 trays in stacks of two, the 2 upper trays containing the wild oysters and the 2 lower trays the tested oysters. Phytoplankton-enriched sea water was delivered at $150 \mathrm{~L} \mathrm{~h}^{-1}$ for each raceway. Raceways were fully emptied and cleaned only once a week, assuming that it would favor the transmission of the parasite between oysters. The position of each stack was changed at each cleaning: the stack furthest from the water inflow was exchanged with the stack closest to the water inflow. Purification of $B$. ostreae was performed as described in Mialhe et al. (1988) and led to the collection of $443 \times 10^{6}$ parasites from a single heavily-infected oyster. This amount of parasites enabled the injection using syringes of $1 \times 10^{6}$ parasites into the heart cavity of 330 wild oysters after their anesthesia using $\mathrm{MgCl}_{2}$ (Culloty and Mulcahy 1992). For each raceway, 16-17 injected wild oysters and 5-6 non-injected wild oysters were put in each upper tray, the lower tray containing 50 tested oysters.

\subsection{Detection of Bonamia ostreae}

Mortality was checked daily from January until July 2006. The 4 trays were lifted out from the water to drain for at least 30 min before inspecting the oysters and removing any that were gaping, characteristic of dead or dying individuals. A heart imprint was performed on each gaping oyster that consisted of dissecting out the ventricle, drying it on paper and then performing several imprints on a slide. After air drying for 5 min, the slide was then stained with Hemacolor ${ }^{\mathbb{R}}$ (Merck). Slides were observed under the light microscope $(\times 1000)$ and the level of infection by the parasite was characterized according to Hervio et al. (1995) into the following categories:

- negative results $\left(\mathrm{B}^{-}\right)$when no parasite was detected after 5 min of screening heart imprints from an individual oyster,

- low infections $\left(\mathrm{B}^{+}\right)$when 10 or fewer parasites were observed during 5 min screening

- moderate infections $\left(\mathrm{B}^{++}\right)$when around one parasite per microscopic field of view was detected,

- heavy infections $\left(\mathrm{B}^{+++}\right)$when several or numerous parasites were observed in each microscopic field of view.

Total shell length (from hinge to outer shell edge) of each dead oyster was measured. Cumulative mortality curves were computed to follow the dynamics of mortality as well as the dynamics of appearance of $B$. ostreae in each raceway.

At the end of the experiment, all remaining oysters from Family 2 were analyzed using heart imprints and the level of infection of the parasite determined as explained above. Oysters from Family 1 were kept alive for further experiments.

\subsection{Statistical analyses}

Comparisons of mortality and detection frequency were performed by $\chi^{2}$ test of independence at the end of the challenge experiment. For comparisons of detection frequency among raceways within each family, 2 classes were considered: no parasite infection $\left(\mathrm{B}^{-}\right)$versus parasite infection
$\left(\mathrm{B}^{+}, \mathrm{B}^{++}\right.$and $\mathrm{B}^{+++}$pooled). For comparison of detection frequency between the 2 families, the 4 classes were considered.

Differences in the total length of the dead oysters according to the level of infection by the parasite $\left(\mathrm{B}^{-}, \mathrm{B}^{+}, \mathrm{B}^{++}\right.$, $\mathrm{B}^{+++}$) were tested for the 2 families by single classification analysis of variance (ANOVA) or by Kruskall-Wallis test (when the data were not normal but the variances were equal). All pairwise comparisons were performed, using Dunn's procedure after Kruskall-Wallis and Bonferroni's method after the ANOVA (MINITAB ${ }^{\circledR}$ Release 14 Statistical Software). In all tests a $p$-value $<0.05$ was considered to be statistically significant.

\section{Results}

\subsection{Mortality and level of infection in the two families}

Cumulative overall mortalities for the wild and tested oysters of the Family 1 and 2 were analyzed for each of the raceways, as well as the cumulative mortalities of oysters that died containing the parasite (Bonamia-positive oysters $\mathrm{B}^{+}, \mathrm{B}^{++}$ and $\mathrm{B}^{+++}$pooled). All the raceways showed a similar pattern, with the first mortalities appearing a few days after the beginning of the experiment in the wild oysters but most mortalities occurring in June and July (140 days post challenge) in the tested oysters. For the two families, no significant differences were found in the number of dead wild oysters nor the detection frequency of the parasite at the end of the experiment among the 5 raceways. Similarly, the number of dead tested oysters and the parasite detection frequencies were homogeneous among the raceways. As a result, data from all 5 raceways were pooled for each tested family.

Over the 6 month period, the cumulative mortality of the wild oysters reached $58.4 \%$. In the last 40 days of the experiment, mortality rate of the wild oysters decreased and the cumulative mortality begins to plateau (Fig. 3). Overall, 66.8\% of the wild oysters that died during the challenge experiment were confirmed, by heart imprint, to have the parasite present. Mortality in the tested families began in April (i.e. 70 days post challenge) and mortality of oysters that were Bonamiapositive occurred in June and July (Fig. 3). In total, 52 oysters of Family 1 died (9.4\%). Reliable heart imprints could not be performed for $11.5 \%$ of these oysters because of the degree of tissue decay; $28.8 \%$ were diagnosed $\mathrm{B}^{-}, 28.9 \% \mathrm{~B}^{+}, 23.1 \%$ $\mathrm{B}^{++}$and $7.7 \%$ were $\mathrm{B}^{+++}$. Among the dead oysters of Family 1 for which a heart imprint could be performed $(n=46)$, the parasite $B$. ostreae could be detected in $67.5 \%$. For Family 2,105 oysters in total died over the 6 month period $(19.1 \%)$. Imprints could not be performed for $9.5 \%$ of them; $9.5 \%$ were $\mathrm{B}^{-}, 16.2 \% \mathrm{~B} 0^{+}, 22.9 \% \mathrm{~B}^{++}$and $41.9 \%$ were $\mathrm{B}^{+++}$. Among the dead oysters of Family 2 for which a heart imprint could be performed $(n=95)$, the parasite $B$. ostreae could be detected in $89 \%$. The mortality was significantly higher in Family 2 than in Family $1\left(\chi^{2}=20.87, p<0.001,1\right.$ d.f. $)$ as well as the intensity of infection by the parasite found in heart imprint $\left(\chi^{2}=24.34, p<0.001,4\right.$ d.f. $)$.

Mean mortalities and levels of infection over 10-day periods are presented to illustrate their temporal trends (Fig. 4). 


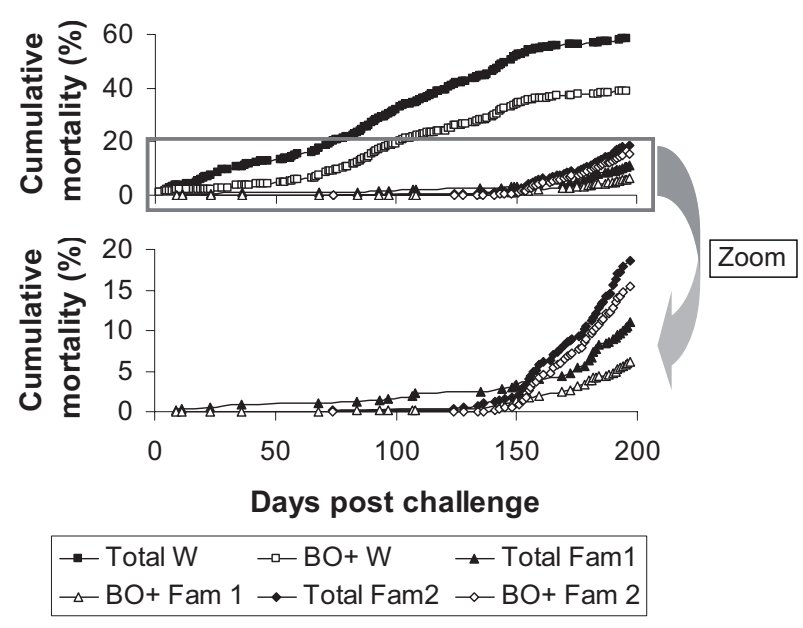

Fig. 3. Cumulative mortalities for the 6 month trial of the challenge experiment. The two upper curves (square) represent the cumulative total mortality (in black $=$ Total $\mathrm{W}$ ) and the cumulative mortality of oysters infected with the parasite (in white $=\mathrm{BO}^{+} \mathrm{W}$ ) for the wild oysters (upper trays). The 4 lower curves represent the total cumulative mortality (in black $=$ Total) and the cumulative mortality of the Bonamia-positive oysters (in white $=\mathrm{B}^{+}$) respectively for the family 1 (triangle) and the family 2 (diamond). Data were pooled across all raceways.

Most of the wild dead oysters that died after the first 50 days of the experiment were moderately to heavily infected with the parasite. It can be seen that the wild oysters died during the whole course of the experiment, potentially leading to a significant source of Bonamia infection for the two tested families. In the last 40 days of the experiment, the number of wild oysters that died decreased (Fig. 4a). For Family 1, the few oysters (but one) dying in the first 130 days of the experiment were negative for the presence of the parasite. After that date, the dead oysters mainly exhibited a low to moderate level of infection and only a few heavily infected oysters could be detected (Fig. 4b). For Family 2, only one oyster, negative for the parasite presence, died during the first 80 days of the experiment and the remaining mortalities began 120 days (4 months) after the beginning of the challenge experiment. Contrary to Family 1, most of the dead oysters of Family 2 were moderately to heavily infected with the parasite (Fig. 4c).

\subsection{Relationship between shell length and level of infection}

Table 1a shows the total length $(\mathrm{cm})$ of the oysters of Family 1 that died during the challenge experiment, depending on their level of infection to the parasite B. ostreae (revealed by heart imprint). The mean length ranged from $5.51 \mathrm{~cm}$ for the heavily infected oysters $\left(\mathrm{B}^{+++}\right)$to $5.92 \mathrm{~cm}$ for the lightly infected ones $\left(\mathrm{B}^{+}\right)$. The data were normally distributed (Anderson-Darling $a^{2}=0.681, p=0.070$ ) and with similar variances (Bartlett's test statistic $=4.23, p=0.238$; Levene's test statistic $=1.05, p=0.381$ ) so were analyzed by single classification ANOVA (Table 1b). No significant difference in the total length of the oysters in the 4 groups of parasite
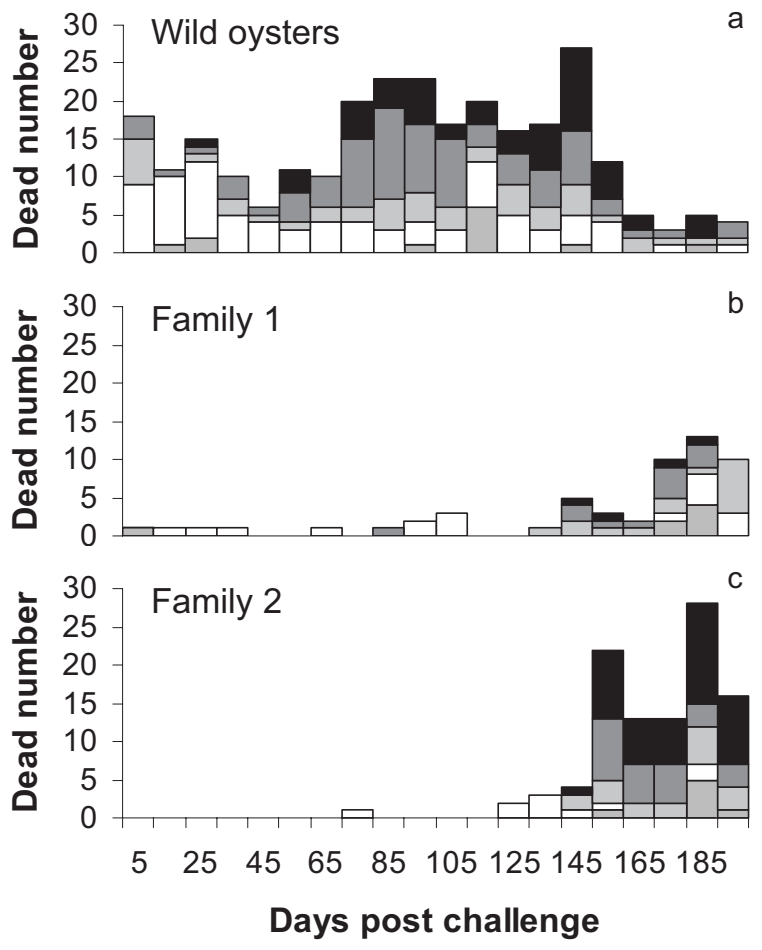

$\square ? \square \mathrm{B} 0-\square \mathrm{B} 0+\square \mathrm{B} 0++\square \mathrm{B} 0+++$

Fig. 4. Kinetics of bonamiosis development for the batch of wild oysters and the two tested families (Family 1 and Family 2). Mortalities were monitored daily and reported every 10 days. Bonamia infection intensities (negative $\left(\mathrm{B}^{-}\right)$, low $\left(\mathrm{B}^{+}\right)$, moderate $\left(\mathrm{B}^{++}\right)$and heavy $\left.\left(\mathrm{B}^{+++}\right)\right)$were determined by examination of heart tissue imprints. ? corresponds to dead oysters for which the infection intensity could not be determined because of tissue decay.

level infection could be observed $\left(F_{3,41}=0.53, p=0.666\right)$ for Family 1.

The mean shell lengths of Family 2 oysters that died during the challenge experiment ranged from $4.28 \mathrm{~cm}$ for the noninfected oysters $\left(\mathrm{B}^{-}\right)$to $5.09 \mathrm{~cm}$ for the heavily infected oysters $\left(\mathrm{B}^{+++}\right)$(Table $\left.2 \mathrm{a}\right)$. The data were not normally distributed (Anderson-Darling $a^{2}=1.908, p<0.005$ ) and could not be made so by log-transformation but exhibited similar variances (Levene's test statistic $=1.16, p=0.328$ ). Therefore the data were analyzed by a Kruskal-Wallis test. Significant difference in the total length of the oysters in the 4 groups of parasite level infection was observed for Family $2(H=8.13$, 3 d.f., $p=0.043)$. However, Dunn's method for all pairwise comparisons between treatment medians revealed no significant differences although the greatest pairwise difference in shell lengths was between $\mathrm{B}^{+++}$and $\mathrm{B}^{-}$(Table $2 \mathrm{~b}$ ).

\subsection{Comparison of the level of infection between the dead and surviving oysters of the Family 2}

All the surviving oysters of Family 2 were analyzed by heart imprint after 6 months. Overall, 444 oysters were analyzed, 94 in raceway 8,85 in raceway 11,87 in raceway 12 , 
Table 1. The results and analysis of Ostrea edulis total length $(\mathrm{cm})$ at date of death according to their level of infection to the parasite Bonamia ostreae during a 6-month challenge experiment (Family 1).

(a) Means, medians and standard deviations of oyster total length (Family 1)

\begin{tabular}{lcccc}
\hline \multicolumn{1}{c}{$\begin{array}{c}\text { Infection } \\
\text { level }\end{array}$} & $N$ & Mean length & Median length & SD \\
\hline B0 $^{-}$ & 14 & 5.58 & 5.64 & 1.05 \\
B0 $^{+}$ & 15 & 5.92 & 5.94 & 0.74 \\
B0 $^{++}$ & 12 & 5.75 & 5.79 & 0.57 \\
B0 $^{+++}$ & 4 & 5.51 & 5.64 & 0.73 \\
\hline
\end{tabular}

(b) Analysis of variance table

\begin{tabular}{lccccc}
\hline Source & $D F$ & SeqSS & $M S$ & $F$ & $p$ \\
\hline Infection level & 3 & 1.05 & 0.3488 & 0.53 & 0.666 \\
Error & 41 & 27.15 & 0.6623 & & \\
Total & 44 & 28.20 & & & \\
\hline
\end{tabular}

Table 2. The results and analysis of Ostrea edulis total length $(\mathrm{cm})$ at date of death according to their level of infection to the parasite Bonamia ostreae during a 6-month challenge experiment (Family 2).

(a) Means, medians and standard deviations of oyster total length (Family 2)

\begin{tabular}{lcccc}
\hline $\begin{array}{l}\text { Infection } \\
\text { level }\end{array}$ & $N$ & Mean length & Median length & $S D$ \\
\hline B0 $^{-}$ & 9 & 4.28 & 4.50 & 1.09 \\
B0 $^{+}$ & 17 & 4.71 & 4.66 & 0.84 \\
B0 $^{++}$ & 23 & 5.05 & 5.15 & 0.52 \\
B0 $^{+++}$ & 44 & 5.09 & 5.02 & 0.88 \\
\hline
\end{tabular}

(b) Multiple comparisons between median total lengths using Dunn's procedure after Kruskal-Wallis analysis. Any rank difference, divided by its standard deviation, which is greater than the given value of 2.63 (SE of difference) is significant at the $5 \%$ level.

Columns are substracted from rows.

\begin{tabular}{llll}
\hline $\begin{array}{l}\text { Infection } \\
\text { level }\end{array}$ & & & \\
$\mathrm{B} 0^{+}$ & 0.53 & & \\
$\mathrm{~B} 0^{++}$ & 1.81 & 1.54 & \\
$\mathrm{~B}^{+++}$ & 2.25 & 2.11 & 0.43 \\
& $\mathrm{~B} 0^{-}$ & $\mathrm{B} 0^{+}$ & $\mathrm{B}^{++}$ \\
\hline
\end{tabular}

95 in raceway 13 and 83 in raceway 14 . Most of them were $\mathrm{B}^{-}(86.2 \%$ for raceway $8,89.4 \%$ for raceway $11,93.1 \%$ for raceway $12,87.4 \%$ for raceway 13 and $88.0 \%$ for raceway 14 ) and almost no $\mathrm{B}^{+++}$oysters were found $(0 \%$ in raceways 8 , $11,12$ and $13 ; 1.2 \%$ in raceway 14$)$. No significant differences between raceways were found for the heart imprint results achieved on the surviving oysters $\left(\chi^{2}=3.92, p=0.864,8\right.$ d.f. after pooling $\mathrm{B}^{++}$and $\mathrm{B}^{+++} ; \chi^{2}=2.55, p=0.636,4$ d.f. after pooling $\mathrm{B}^{+}, \mathrm{B}^{++}$and $\mathrm{B}^{+++}$). Therefore, data among the 5 raceways were pooled. Overall, $88.7 \%$ of the surviving oysters were not infected with the parasite $\left(\mathrm{B}^{-}\right), 8.4 \%$ were slightly infected $\left(\mathrm{B}^{+}\right), 2.7 \%$ were moderately infected $\left(\mathrm{B}^{++}\right)$ and only $0.2 \%$ were heavily infected $\left(\mathrm{B}^{+++}\right)$. The difference in the detection frequency between the 2 groups of oysters (dead, surviving) in Family 2 was striking: $89 \%$ against $11 \%$ of
Family 2. Dead ( $=95)$

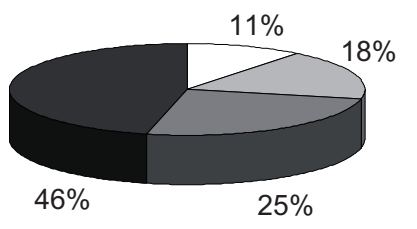

$\square \mathrm{BO}^{-} \square \mathrm{BO}^{+} \square \mathrm{BO}^{++} \square \mathrm{BO}^{+++}$
Family 2. Surviving $(n=444)$

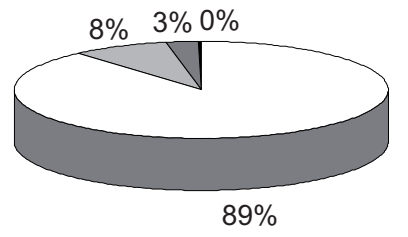

$89 \%$
Fig. 5. Comparison of the level of infection of the parasite (after heart imprint) between the two groups of oysters of Family 2, the 95 that died during the 6-month trial (for which a heart imprint could be performed) and the 444 that survived the challenge experiment.

Bonamia-positive in the dead or surviving groups, respectively (Fig. 5).

\section{Discussion}

\subsection{Challenge experiment}

Field testing and experimental infection by injection of purified parasite have been widely used for epidemiological studies or in the context of a selective breeding program for resistance to bonamiosis. These methods proved efficient to transmit bonamiosis to flat oysters, leading in some cases to a high percentage of mortality associated with a high prevalence of the parasite (e.g. Tigé and Grizel 1984; Elston et al. 1986; Mialhe et al. 1988; Naciri-Graven et al. 1998).

Cohabitation was chosen in our study because it is likely to mimic the mode of transmission of the disease in the wild. Challenge by injection creates stress and tissue lesion, and would bypass the natural pathway of entry of the parasite into the oyster. Most cohabitation experiments performed so far did not involve the injection of purified parasite in the source oysters (Elston et al. 1986; Elston et al. 1987; Martin et al. 1993; Culloty et al. 1999). In our study, however, wild oysters were injected with the parasite in order to increase the parasite burden in each raceway and to create a "Bonamia pump". It was anticipated that injected wild oysters would infect the noninjected ones before their own death and that this would maintain a high parasite pressure during the course of the experiment. Bonamia-positive wild oysters were detected throughout the challenge experiment, indicating the usefulness of this approach (Figs. 3 and 4). Finally, this approach allows some control on the parasite pressure applied because a known number of purified parasites is injected in a known number of oysters, and has proven efficient to infect naïve flat oysters (Culloty et al. 1999).

\subsection{Detection of Bonamia ostreae}

Several diagnostic tools have been used so far for the detection of the parasite B. ostreae, either based on light microscopy observation (tissue imprints, haemolymph cell monolayers and histological sections) or PCR-based techniques by amplifying 
portions of the $18 \mathrm{~S}$ rDNA or the ITS of the parasite (Carnegie et al. 2000; Cochennec et al. 2000). In this study, we chose to perform heart imprint for the detection of $B$. ostreae because this methodology is easy, quick, performed at a low cost and allows high throughput of the data. Heart imprints have been used as a diagnostic tool for the detection of $B$. ostreae in numerous studies (Martin et al. 1993; Hervio et al. 1995; Culloty and Mulcahy 1996; Naciri-Graven et al. 1998; Culloty et al. 1999; Culloty et al. 2004; Lynch et al. 2005) (Annex 1). However, Balseiro et al. (2006) reported that the PCR methodology showed a higher sensitivity than histological and cytological studies particularly at the early stages of infection. An advantage of the heart imprint method is that a semi-quantitative scale for the level of infection with the parasite can be used $\left(\mathrm{B}^{-}, \mathrm{B}^{+}, \mathrm{B}^{++}\right.$or $\left.\mathrm{B}^{+++}\right)$contrary to a $\mathrm{PCR}$ assay in which the band is either present or absent.

Several studies have reported the use of quantitative PCR for the detection of Bonamia species. Corbeil et al. (2006), Marty et al. (2006) employed a real-time PCR assay (18S rDNA gene) but the detection did not succeed in being quantitative. Nevertheless, this methodology was faster and increased the sensitivity at low prevalence and severity. A reliable Q-PCR assay for a quantitative estimation of the number of copies of the parasite requires further optimization and standardization (Corbeil et al. 2006).

\subsection{Factors controlling transmission of the disease}

The first mortalities and infections in the tested oysters occurred in May, i.e. after 4 months of cohabitation (Fig. 3). This compares favorably with the previously reported period of 3 to 6 months for transmission (Poder et al. 1982; Tigé and Grizel 1984; Grizel 1985; Elston et al. 1986; Montes 1991; Hervio et al. 1995; Culloty and Mulcahy 1996; Culloty et al. 2004) (Annex 1). However, some studies of field testing reported a longer time for the transmission of the disease, from 6 to 12 months (Culloty et al. 1999; Montes et al. 2003) (Annex 1). In contrast, experimental infection by direct injection of purified parasite could lead to the first detection of the parasite after only 2 months (Mialhe et al. 1988; Hervio et al. 1995) (Annex 4).

The parallel evolution of the total cumulative mortality and the Bonamia-positive cumulative mortality (Fig. 3) led us to conclude that the mortalities observed were most probably due to the parasite $B$. ostreae. However, there was a delay in the detection of the first infections. For example, the wild oysters dying in the first 50 days of the challenge experiment were mainly negative for the parasite or slightly infected (Fig. 4a). This early mortality among the wild oysters was probably due to the stress associated with their transport from Quiberon to La Tremblade, or could be due to tissue damage during the injection process. In the same way, the tested oysters dying first were negative for the presence of the parasite, which could reflect the prepatent period (Fig. 4b,c). However we cannot exclude the hypothesis that some negative $\left(\mathrm{B}^{-}\right)$individuals might correspond to "false negative" results due to the low sensitivity of heart imprints.

Successful transmission of the disease occurred in both families, but mortalities occurred faster in Family 2
(8 month-old at the beginning of the experiment) than in Family 1 (20 month-old at the beginning of the experiment) $\left(\chi^{2}=\right.$ 20.87, $p<0.001,1$ d.f.). Also, the infection frequency was significantly lower in Family 1 than in Family $2\left(\chi^{2}=24.34\right.$, $p<0.001,4$ d.f.). The cumulative mortalities observed in the 2 families were relatively low (9\% in Family 1 and 20\% in Family 2, Fig. 3) compared with the study of Culloty et al. (1999) where a 6-month cohabitation trial (injected oysters/naive oysters) resulted in a $32 \%$ cumulative mortality in the group of oysters from an area free of B. ostreae. A lower parasite pressure in our study could explain the lower cumulative mortality observed in our tested families. Indeed, only $1 \times 10^{6}$ parasites were injected in each of 160 source oysters (for 500 tested oysters), compared with $5 \times 10^{6}$ parasites in each of 100 source oysters (for 150 tested oysters) in Culloty et al. (1999) (Annex 3 ). However, this lower cumulative mortality might reflect the genetic background of our oysters for which one parent came from a selected strain.

Transmission of the disease also depends on environmental factors such as temperature, salinity or physical manipulation. Indeed, Hine et al. (2002) showed that extreme environmental factors and physical manipulation increased the transmission of Bonamia exitiosa to Ostrea chilensis, as does crowding among B. exitiosa-infected oysters. Audemard et al. (2008) performed laboratory experiments suggesting that warm temperature and high salinity (30 psu) increased Bonamia sp. pathogenicity in the Asian oyster Crassostrea ariakensis. However, in our study, the two families were held in the same environmental conditions and were subjected to the same manual handling, so non-environmental factors are likely to be responsible for the differences between the two families in the level of the transmission of the disease.

Eight month-old oysters, Family 2, presented higher mortality and detection frequency to the parasite than the 20 month-old oysters, Family 1. This result was inconsistent with the findings of Culloty and Mulcahy (1996) that suggested that 2 year-old was the critical age for the disease development. Therefore, age may not be the key factor in development of the disease, but one of several genetic or environmental factors (Cacéres-Martínez et al. 1995). Indeed, Lynch et al. (2005) followed the prevalence and intensity of infection in young prespawning oysters (1-3 month-old to 18 month-old) by heart imprint and PCR techniques and confirmed that such young oysters were susceptible to bonamiosis although they did not report mortality data: after 6 months in the field, prevalence was less than $10 \%$ in oysters being 1-3 month-old at the beginning of the experiment (Annex 1). We have shown both susceptibility of young oysters to the disease and mortalities in our experimental conditions.

The most probable cause of the discrepancy in the development of the disease between the 2 tested families was a difference in their genetic background. Both families originated from a cross between a wild oyster and an oyster derived from the IFREMER selective breeding program. However, only Family 2 was directly derived from a selected family (family 98AC703 produced in 1998) (Fig. 2) that had been tested for its resistance to bonamiosis both in the field and by injection. In contrast, Family 1 originated from a $6^{\text {th }}$ generation inbred line that showed no mortality in the field but 
whose resistance was not tested by inoculations (Fig. 1). Moreover, because the two families issued from crosses involving two different wild oysters, differences in the rate of infection between the two families could be due to differences in the genomes of the wild oyster parents.

Finally, the heart imprints performed on the surviving oysters of Family 2 (Fig. 5) revealed that $89 \%$ of the surviving oysters were not infected by B. ostreae. Even if some of those $\mathrm{B}^{-}$oysters might be slightly infected (due to the low sensitivity of the heart imprint technique), the majority of them are probably truly not infected. Therefore, these results suggest a resistance rather than a tolerance of infection by the parasite.

\subsection{Potential implications for the management of flat oysters stocks}

Producers commonly observe that mortalities occur in the field in 2.5-3 year-old flat oysters (i.e. when they reach market size). However, our experiment demonstrates for the first time that one year-old oysters can die due to $B$. ostreae infection. Even if no mortality in the spat has so far been reported in the natural environment, our results suggest that specific conditions (such as close contact of spat with infected adult oysters or density) can induce mortalities in such young oysters in relation with the infection to Bonamia ostreae. Therefore the potential impact of $B$. ostreae on the dynamics of flat oyster stocks should be further investigated, as early mortality has a more important impact than later one when individuals have already reproduced. However, such phenomenon might favor the natural selection of the more resistant oysters, since the fitness difference between "susceptible" and "resistant" genotypes would be increased in case of earlier mortality.

Acknowledgements. This work was funded by INTERREG IIIB (Atlantic Aquaculture Arc Group, AAAG). The authors would like to thank Dr. Frederico Batista for his useful comments on the manuscript. We thank anonymous reviewers for useful comments and suggestions.

\section{References}

Audemard C., Carnegie R.B., Bishop M.J., Peterson C.H., Burreson E.M., 2008, Interacting effects of temperature and salinity on Bonamia sp. parasitism in the Asian oyster Crassostrea ariakensis. J. Invertebr. Pathol. 98, 344-350.

Balouet G., Poder J., Cahour A., 1983, Haemocytic parasitosis: morphology and pathology of lesions in the French flat oyster, Ostrea edulis L. Aquaculture 34, 1-14

Balseiro P., Conchas R.F., Montes J., Gómez-León J., Novoa B., Figueras A., 2006, Comparison of diagnosis techniques for the protozoan parasite Bonamia ostreae in flat oyster Ostrea edulis. Aquaculture 261, 1135-1143.

Barber B.J., Davis C.V., 1994, Prevalence of Bonamia ostreae in Ostrea edulis populations in Maine. J. Shellfish Res. 13, 298.

Bucke D., Hepper B., Key D., Bannister C.A., 1984, A report on Bonamia ostreae in Ostrea edulis in the UK. ICES C.M. 1984/K 9, 1-7.
Cáceres-Martínez J., Robledo J.A.F., Figueras A., 1995, Presence of Bonamia and its relation to age, growth rates and gonadal development of the flat oyster, Ostrea edulis, in the Ria de Vigo, Galicia (NW Spain). Aquaculture 130, 15-23.

Carnegie R.B., Barber B.J., Culloty S.C., Figueras A.J., Distel D.L., 2000, Development of a PCR assay for detection of the oyster pathogen Bonamia ostreae and support for its inclusion in the Haplosporidia. Dis. Aquat. Org. 42, 199-206.

Cochennec-Laureau N., Auffret M., Renault T., Langlade A., 2003, Changes in circulating and tissue-infiltrating hemocyte parameters of European flat oysters, Ostrea edulis, naturally infected with Bonamia ostreae. J. Invertebr. Pathol. 83, 23-30.

Cochennec N., Le Roux F., Berthe F., Gérard A., 2000, Detection of Bonamia ostreae based on small subunit ribosomal probe. J. Invertebr. Pathol. 76, 26-32.

Comps M., Duthoit J.L., 1976, Infection virale associée à la "maladie des branchies" de l'huître portugaise Crassostrea angulata Lmk. C. R. Acad. Sci. Paris 283, Ser. D, 1595-1596.

Comps M., Tigé G., Grizel H., 1980, Étude ultrastructurale d'un Protiste parasite de l'huître Ostrea edulis L. C. R. Acad. Sci. Paris 290, Ser. D, 383-385.

Corbeil S., Arzul I., Diggles B., Heasman M., Chollet B., Berthe F.C.J., Crane M.S.J., 2006, Development of a TaqMan PCR assay for the detection of Bonamia species. Dis. Aquat. Org. 71, 75-80.

Culloty S.C., Cronin M.A., Mulcahy M.F., 2004, Potential resistance of a number of populations of the oyster Ostrea edulis to the parasite Bonamia ostreae. Aquaculture 237, 41-58.

Culloty S.C., Mulcahy M.F., 1992, An evaluation of anaesthetics for Ostrea edulis (L.). Aquaculture 107, 249-252.

Culloty S.C., Mulcahy M.F., 1996, Season-, age-, and sex-related variation in the prevalence of bonamiasis in flat oysters (Ostrea edulis L.) on the south coast of Ireland. Aquaculture 144, 53-63.

Culloty S.C., Novoa B., Pernas M., Longshaw M., Mulcahy M.F., Feist S.W., Figueras A., 1999, Susceptibility of a number of bivalve species to the protozoan parasite Bonamia ostreae and their ability to act as vectors for this parasite. Dis. Aquat. Org. 37, 7380.

Elston R.A., Farley C.A., Kent M.L., 1986, Occurrence and significance of bonamiasis in European flat oysters Ostrea edulis in North America. Dis. Aquat. Org. 2, 49-54.

Elston R.A., Kent M.L., Wilkinson M.T., 1987, Resistance of Ostrea edulis to Bonamia ostreae infection. Aquaculture 64, 237-242.

Figueras A.J., 1991, Bonamia status and its effects in cultured flat oysters in the Ria de Vigo, Galicia (N.W. Spain). Aquaculture 93, 225-233.

Food and Agriculture Organization of the United Nations (FAO), 2007, FishStat, http://www.fao.org/fi/statist/FISOFT/ FISHPLUS.asp

Friedman C.S., McDowell T., Groff J.M., Hollibaugh J.T., Manzer D., Hedrick R.P., 1989, Presence of Bonamia ostreae among populations of the European flat oyster, Ostrea edulis Linnaeus, in California, USA. J. Shellfish Res. 8, 133-137.

Friedman C.S., Perkins F.O., 1994, Range extension of Bonamia ostreae to Maine, USA. J. Invertebr. Pathol. 64, 179-181.

Grizel H., 1985, Etudes des récentes épizooties de l'huître plate Ostrea edulis L. et de leur impact sur l'ostréiculture bretonne. Thèse de doctorat, USTL Montpellier. 
Hervio D., Bachère E., Boulo V., Cochennec N., Vuillemin V., Le Coguic Y., Cailletaux G., Mazurie J., Mialhe E., 1995, Establishment of an experimental infection protocol for the flat oyster, Ostrea edulis, with the intrahaemocytic protozoan parasite, Bonamia ostreae: application in the selection of parasiteresistant oysters. Aquaculture 132, 183-194.

Hine P.M., Diggles B.K., Parsons M.J.D., Pringle A., Bull B., 2002, The effects of stressors on the dynamics of Bonamia exitiosus Hine, Cochennec-Laureau \& Berthe, infections in flat oysters Ostrea chilensis (Philippi). J. Fish Dis. 25, 545-554.

Jaziri H., 1985, Biogéographie et polymorphisme enzymatique chez l'huître plate Ostrea edulis L. 1758. Mémoire de DEA, USTL Montpellier.

Lapègue S., Bédier E., Goyard E., Dégremont L., Baud J.-P., Gérard A., Goulletquer P., Boudry P., 2004, Apport d'un programme de génétique à une filière de production aquacole: l'exemple de l'ostréiculture. In: Trente ans de crevetticulture en NouvelleCalédonie. Actes Colloq. IFREMER 38, 113-121.

Lallias D., 2007, Genetic linkage mapping in the blue mussel Mytilus edulis and the European flat oyster Ostrea edulis, and the search for Quantitative Trait Loci of resistance to a disease in O. edulis. $\mathrm{PhD}$ thesis, University of Wales, Bangor, College of Natural Sciences, School of Ocean Sciences.

Launey S., 1998, Marqueurs microsatellites chez l'huître plate Ostrea edulis L. : caractérisation et applications à un programme de sélection pour une résistance au parasite Bonamia ostreae et à l'étude de populations naturelles. Thèse de doctorat. Institut national agronomique Paris-Grignon.

Launey S., Barre M., Gérard A., Naciri-Graven Y., 2001, Population bottleneck and effective size in Bonamia ostreae-resistant populations of Ostrea edulis as inferred by microsatellite markers. Genet. Res. 78, 259-270.

Le Dantec J., Marteil L., 1976, La reproduction des huîtres. Rev. Trav. Inst. Pêches Marit. 40, 233-256.

Lynch S.A., Armitage D.V., Coughlan J., Mulcahy M.F., Culloty S.C., 2007, Investigating the possible role of benthic macroinvertebrates and zooplankton in the life cycle of the haplosporidian Bonamia ostreae. Exp. Parasitol. 115, 359-368.

Lynch S.A., Armitage D.V., Wylde S., Mulcahy M.F., Culloty S.C., 2005, The susceptibility of young, prespawning oysters, Ostrea edulis, to Bonamia ostreae. J. Shellfish Res. 24, 1019-1025.

Martin A.-G., Gérard A., Cochennec N., Langlade A., 1993, Selecting flat oysters, Ostrea edulis, for survival against the parasite Bonamia ostreae: assessment of the resistance of a first selected generation. In: Barnabé G., Kestemont P. (Eds.), Production, Environment and Quality. Bordeaux Aquaculture 1992. Eur. Aquac. Soc. Spec. Publ. No. 18, pp. 547-554.

Marty G.D., Bower S.M., Clarke K.R., Meyer G., Lowe G., Osborn A.L., Chow E.P., Hannah H., Byrne S., Sojonky K., Robinson
J.H., 2006, Histopathology and a real-time PCR assay for detection of Bonamia ostreae in Ostrea edulis cultured in western Canada. Aquaculture 261, 33-42.

McArdle J.F., McKiernan F., Foley H., Jones D.H., 1991, The current status of Bonamia disease in Ireland. Aquaculture 93, 273-278.

Mialhe E., Bachère E., Chagot D., Grizel H., 1988, Isolation and purification of the protozoan Bonamia ostreae (Pichot et al. 1980), a parasite affecting the flat oyster Ostrea edulis L. Aquaculture 71, 293-299.

Montes J., 1990, Development of Bonamia ostreae parasitosis of flat oyster, Ostrea edulis, from Galicia, northwest Spain. In: Perkins F.O., Cheng T.C. (Eds.) Pathology in Marine Science, Academic Press, San Diego, CA.

Montes J., 1991, Lag time for the infestation of flat oyster (Ostrea edulis L.) by Bonamia ostreae in estuaries of Galicia (N.W. Spain). Aquaculture 93, 235-239.

Montes J., Ferro-Soto B., Conchas R.F., Guerra A., 2003, Determining culture strategies in populations of the European flat oyster, Ostrea edulis, affected by bonamiosis. Aquaculture 220, 175-182.

Montes J., Melendez M.I., 1987, Données sur la parasitose de Bonamia ostreae chez l'huître plate de Galice, côte nord-ouest de l'Espagne. Aquaculture 67, 195-198.

Naciri-Graven Y., Martin A.-G., Baud J.-P., Renault T., Gérard A., 1998, Selecting the flat oyster Ostrea edulis (L.) for survival when infected with the parasite Bonamia ostreae. J. Exp. Mar. Biol. Ecol. 224, 91-107.

Pichot Y., Comps M., Tigé G., Grizel H., Rabouin M.A., 1979, Recherches sur Bonamia ostreae gen. n., sp. n., parasite nouveau de l'huître plate Ostrea edulis L. Rev. Trav. Inst. Pêches Marit. 43, 131-140.

Poder M., Cahour A., Balouet G., 1982, Hemocytic parasitosis in European oyster Ostrea edulis L.: pathology and contamination. Proc. 15th annual meeting of the society for invertebrate pathology, Brighton, pp. 254-257.

Tigé G., Grizel H., 1984, Essai de contamination d'Ostrea edulis Linné par Bonamia ostreae (Pichot et al., 1979) en rivière de Crach (Morbihan). Rev. Trav. Inst. Pêches Marit. 328, 3-13.

Van Banning P., 1985, Control of Bonamia in Dutch oyster culture. In: Ellis A.E. (Ed.), Fish and Shellfish Pathology. Academic Press, London, pp. 393-396.

Van Banning P., 1991, Observations on bonamiasis in the stock of the European flat oyster, Ostrea edulis, in the Netherlands, with special reference to the recent developments in Lake Grevelingen. Aquaculture 93, 205-211.

Walne P.R., 1974, Culture of bivalve molluscs: fifty years experience at Conwy. Whitefriars Press Ltd, London.

Yonge C.M., 1960, Oysters. The New Naturalist, Collins, London. 
Annexes 1 to 4. Review of the different methods used to infect the European flat oyster Ostrea edulis with Bonamia ostreae; mo: month.

Annex 1. Field testing.

\begin{tabular}{|c|c|c|c|c|c|c|c|c|c|}
\hline \multirow[t]{2}{*}{ Reference } & \multicolumn{3}{|c|}{ Technical information } & & & \multicolumn{4}{|c|}{ Results } \\
\hline & $N$ tested oysters & $\begin{array}{c}\text { Age } \\
\text { tested } \\
\text { oysters }\end{array}$ & Duration & $\begin{array}{l}\text { Diagnostic } \\
\text { method }\end{array}$ & $\%$ mortality & $\begin{array}{l}\text { \% parasite } \\
\text { detection }\end{array}$ & $\begin{array}{l}\text { Time before } \\
\text { first } \\
\text { mortalities }\end{array}$ & $\begin{array}{l}\text { Level of } \\
\text { observed } \\
\text { infection }\end{array}$ & $\begin{array}{l}\text { Relation } \\
\text { with } \\
\text { age/size }\end{array}$ \\
\hline Poder et al. (1982) & $\begin{array}{l}1500 \text { healthy } \\
\text { immersed in contaminated } \\
\text { areas; } 4 \text { different sites; } 15 \\
\text { oysters tested each month }\end{array}$ & $\begin{array}{l}\text { 3-4 years } \\
\text { old }\end{array}$ & $8 \mathrm{mo}$ & histology & $\begin{array}{l}\text { only infection } \\
\text { data because } \\
\text { sampling of } \\
\text { only }\end{array}$ & $\begin{array}{c}7-80 \% \text { after } 8 \mathrm{mo}, \\
\text { depending on the } \\
\text { site }\end{array}$ & $\begin{array}{l}\text { 3-7 mo before } \\
\text { first infections }\end{array}$ & - & - \\
\hline $\begin{array}{l}\text { Tigé and Grizel } \\
\text { (1984) }\end{array}$ & $\begin{array}{l}7 \text { batches of } 800 \text { oysters. } \\
\text { Each batch put in the field } \\
\text { at a different time of the } \\
\text { year (march to november) }\end{array}$ & Unknown & $12 \mathrm{mo}$ & histology & $\begin{array}{c}25-60 \% \text { after } 7 \mathrm{mo} \\
70-90 \% \\
\text { after } 10-12 \mathrm{mo}\end{array}$ & $\begin{array}{c}\text { 6.6-52\% after 5-6 mo, } \\
\text { depending on } \\
\text { the time of } \\
\text { immersion }\end{array}$ & $4-5 \mathrm{mo}$ & - & - \\
\hline Montes (1991) & $\begin{array}{l}\text { sampling after } 3 \text { and } 6 \\
\text { months in } 3 \text { estuaries; } \\
\text { density } 600 \text { oysters per } \\
\text { rope (rafts of } 500 \mathrm{~m}^{2} \text { with } \\
500 \text { ropes); total of } 1418 \\
\text { oysters tested }\end{array}$ & Unknown & $6 \mathrm{mo}$ & $\begin{array}{l}\text { histology } \\
\text { and } \\
\text { imprint }\end{array}$ & - & $\begin{array}{c}0-9 \% \text { after } 3 \\
\text { months; } 9-31 \% \\
\text { after } 6 \text { mo }\end{array}$ & $\begin{array}{l}3 \text { mo before } \\
\text { first infections }\end{array}$ & - & - \\
\hline Martin et al. (1993) & $\begin{array}{l}150 \text { oysters per bag, } 3 \text { to } 5 \\
\text { bags per lot; oysters from } \\
\text { programme of selection to } \\
\text { bonamiosis (selected) and } \\
\text { control (not selected) }\end{array}$ & $\begin{array}{l}21 \mathrm{mo} \\
\text { old }\end{array}$ & $7 \mathrm{mo}$ & $\begin{array}{l}\text { heart and } \\
\text { digestive } \\
\text { gland } \\
\text { imprint }\end{array}$ & $\begin{array}{l}34 \% \text { (control); } \\
7 \% \text { (selected) }\end{array}$ & $\begin{array}{l}47 \% \text { (control) and } \\
9 \% \text { (selected) after } \mathrm{g} \\
7 \text { mo in surviving }\end{array}$ & $\begin{array}{l}\text { only final } \\
\text { sampling }\end{array}$ & - & - \\
\hline $\begin{array}{c}\text { Cáceres-Martínez et al. } \\
\text { (1995) }\end{array}$ & $\begin{array}{l}3 \text { size groups of oysters } \\
\text { (small, medium, large) } \\
\text { placed in baskets on rafts; } \\
20-30 \text { oysters of each } \\
\text { group collected monthly }\end{array}$ & $\begin{array}{c}18 \text { mo } \\
\text { old }\end{array}$ & $8 \mathrm{mo}$ & histology & $\begin{array}{l}>40 \% \text { (small } \\
\text { and medium); } \\
32 \% \text { (large) }\end{array}$ & $\begin{array}{l}20-30 \% \text { at the last } \\
\text { sampling date, no } \\
\text { cumulative data }\end{array}$ & $\begin{array}{c}0-2-4 \text { mo } \\
\text { (large, } \\
\text { medium and } \\
\text { small } \\
\text { respectively) } \\
\text { for first } \\
\text { infections }\end{array}$ & - & $\begin{array}{c}\text { positive } \\
\text { relation } \\
\text { between } \\
\text { Bonamia } \\
\text { presence } \\
\text { and mean } \\
\text { total length }\end{array}$ \\
\hline
\end{tabular}




\begin{tabular}{|c|c|c|c|c|c|c|c|c|c|}
\hline \multirow[t]{2}{*}{ Reference } & \multicolumn{3}{|c|}{$\begin{array}{l}\text { Technical information } \\
\end{array}$} & \multirow[b]{2}{*}{$\begin{array}{l}\text { Diagnostic } \\
\text { method }\end{array}$} & \multirow[b]{2}{*}{$\%$ mortality } & \multicolumn{4}{|c|}{ Results } \\
\hline & $N$ tested oysters & $\begin{array}{c}\text { Age } \\
\text { tested } \\
\text { oysters }\end{array}$ & Duration & & & $\begin{array}{l}\text { \% parasite } \\
\text { detection }\end{array}$ & $\begin{array}{l}\text { Time before } \\
\text { first } \\
\text { mortalities }\end{array}$ & $\begin{array}{l}\text { Level of } \\
\text { observed } \\
\text { infection }\end{array}$ & $\begin{array}{l}\text { Relation } \\
\text { with } \\
\text { age/size }\end{array}$ \\
\hline $\begin{array}{c}\text { Culloty and } \\
\text { Mulcahy (1996) }\end{array}$ & $\begin{array}{l}2 \text { age groups, oyster beds, } \\
\text { no initial prevalence; } \\
\text { mortality recorded, } \\
\text { sampling of } 58 \text { live oysters } \\
\text { of each group at each } \\
\text { sampling time (every } \\
\text { months for } 1.5 \text { y-o group; } \\
11 \text { times for } 2.5 \text { y-o group) }\end{array}$ & $\begin{array}{c}1.5-2.5 \\
\text { years old }\end{array}$ & & $\begin{array}{l}\text { histology } \\
\text { and heart } \\
\text { imprint }\end{array}$ & $\begin{array}{c}8-58 \%(1.5 \\
\text { years-old } \\
\text { stock, 10-64\% } \\
\text { (2.5 years-old } \\
\text { stock) } \\
\text { depending on } \\
\text { sampling } \\
\text { month }\end{array}$ & $\begin{array}{c}0-65 \%(1.5 \text { years- } \\
\text { old stock); } 18- \\
70 \%(2.5 \text { years- } \\
\text { old stock } \\
\text { depending on } \\
\text { sampling month }\end{array}$ & $\begin{array}{c}2.5 \text { years-old } \\
\text { stock already } \\
\text { infected at the } \\
\text { beginning of } \\
\text { the } \\
\text { experiment; } \\
\text { first infections } \\
\text { after } 6 \text { months } \\
\text { for } 1.5 \text { years- } \\
\text { old stock }\end{array}$ & $\begin{array}{c}0-9 \%(1.5 \\
\text { y-o); } 0- \\
28 \%(2.5 \\
\text { y-o) of } \\
+++ \\
\text { depending } \\
\text { on the } \\
\text { sampling } \\
\text { month }\end{array}$ & $\begin{array}{l}\text { relation } \\
\text { with age } \\
\text { (first } \\
\text { infections } \\
\text { when age } \\
\text { 2-year-old) }\end{array}$ \\
\hline \multirow[t]{3}{*}{$\begin{array}{c}\text { Naciri-Graven et al. } \\
\text { (1998) }\end{array}$} & $\begin{array}{c}3 \text { bags containing each } 263 \\
\text { oysters } 3^{\text {rd }} \text { generation } \\
\text { selected strain S85 } \\
\text { (selected); } 3 \text { bags } \\
\text { containing each } 288 \\
\text { oysters (control) }\end{array}$ & 4 mo old & $20 \mathrm{mo}$ & $\begin{array}{l}\begin{array}{c}\text { heart or } \\
\text { gill } \\
\text { imprints }\end{array}\end{array}$ & $\begin{array}{c}40.9 \% \\
\text { (selected); } \\
86.5 \% \text { (control) }\end{array}$ & $\begin{array}{l}22.7 \% \text { (selected); } \\
48.9 \% \text { (control) at } \\
\text { the end of } \\
\text { experiment, on } \\
\text { experiment, on } \\
\text { surviving oysters }\end{array}$ & $\begin{array}{c}\text { mortality } \\
<10 \% \text { until } 8^{\text {th }} \\
\text { month }\end{array}$ & - & \multirow[t]{3}{*}{$\begin{array}{l}\text { tendency } \\
\text { towards } \\
\text { higher } \\
\text { weights in } \\
\text { selected } \\
\text { strains }\end{array}$} \\
\hline & $\begin{array}{l}3 \text { bags containing each } 239 \\
\text { oysters } 2^{\text {nd }} \text { generation } \\
\text { selected strain S } 89 \\
\text { (selected); } 3 \text { bags } \\
\text { containing each } 231 \\
\text { oysters (control) }\end{array}$ & $\begin{array}{c}11 \text { mo } \\
\text { old }\end{array}$ & $19 \mathrm{mo}$ & $\begin{array}{l}\begin{array}{l}\text { heart or } \\
\text { gill } \\
\text { imprints }\end{array}\end{array}$ & $\begin{array}{c}46.6 \% \\
\text { (selected); } \\
51.7 \% \text { (control) }\end{array}$ & $\begin{array}{l}12.5 \% \text { (selected); } \\
21.1 \% \text { (control) at } \\
\text { the end of } \\
\text { experiment, on } \\
\text { surviving oysters }\end{array}$ & - & - & \\
\hline & $\begin{array}{l}12 \text { bags containing each } \\
223 \text { oysters cross between } \\
\text { two selected strains } S 85 \\
\text { and } S 89 \text { (selected); } 12 \\
\text { bags containing each } 269 \\
\text { oysters (control) }\end{array}$ & 5 mo old & $22 \mathrm{mo}$ & $\begin{array}{l}\text { heart or } \\
\text { gill } \\
\text { imprints }\end{array}$ & $\begin{array}{c}60.6 \% \\
\text { (selected); } \\
83.9 \% \text { (control) }\end{array}$ & $\begin{array}{l}47.2 \% \text { (selected); } \\
64 \% \text { (control) at } \\
\text { the end of } \\
\text { experiment, on } \\
\text { surviving oysters }\end{array}$ & - & - & \\
\hline Culloty et al. (1999) & $\begin{array}{l}327 \text { oysters placed in a bag } \\
(1 \times 0.5 \mathrm{~m}) \text { on trestle, area } \\
\text { exposed at low spring tide } \\
\text { only, bag } 40 \mathrm{~cm} \text { off the } \\
\text { bed; } 30 \text { oysters tested after } \\
0,1,2,5 \text { or } 10 \text { months; } \\
\text { contaminated area }\end{array}$ & Unknown & $10 \mathrm{mo}$ & $\begin{array}{l}\text { heart } \\
\text { imprint }\end{array}$ & $\begin{array}{c}14 \% \text { after } 2 \\
\text { mo, } 24.7 \% \\
\text { after } 10 \mathrm{mo}\end{array}$ & $\begin{array}{c}25 \% \text { after } 10 \mathrm{mo}, \\
\text { on surviving } \\
\text { oysters }\end{array}$ & $\begin{array}{c}\text { 6-10 } \\
\text { before first } \\
\text { infections }\end{array}$ & - & - \\
\hline
\end{tabular}


Annex 1. Continued.

\begin{tabular}{|c|c|c|c|c|c|c|c|c|c|}
\hline \multirow[t]{2}{*}{ Reference } & \multicolumn{3}{|c|}{ Technical information } & \multirow[b]{2}{*}{$\begin{array}{l}\text { Diagnostic } \\
\text { method }\end{array}$} & \multirow[b]{2}{*}{$\%$ mortality } & \multicolumn{4}{|c|}{ Results } \\
\hline & $N$ tested oysters & $\begin{array}{c}\text { Age } \\
\text { tested } \\
\text { oysters }\end{array}$ & Duration & & & $\begin{array}{l}\% \text { parasite } \\
\text { detection }\end{array}$ & $\begin{array}{l}\text { Time before } \\
\text { first } \\
\text { mortalities }\end{array}$ & $\begin{array}{l}\text { Level of } \\
\text { observed } \\
\text { infection }\end{array}$ & $\begin{array}{l}\text { Relation } \\
\text { with } \\
\text { age/size }\end{array}$ \\
\hline Montes et al. (2003) & $\begin{array}{c}3 \text { hatchery-produced } \\
\text { stocks cultivated on rafts } \\
\text { in a contaminated area; } \\
\text { sampling of at least } 30 \\
\text { oysters of each stock every } \\
3 \text { months }\end{array}$ & 4 mo old & $24 \mathrm{mo}$ & histology & $\begin{array}{c}8-28 \% \text { after } 9 \\
\text { mo; } 32-55 \% \\
15 \text { mo; } \\
74-100 \% \text { after } \\
21 \mathrm{mo}\end{array}$ & $\begin{array}{c}13-27 \% \text { after } 15 \\
\text { mo;33-60\% after } \\
21 \text { mo }\end{array}$ & $\begin{array}{l}12 \text { mo before } \\
\text { first }\end{array}$ & - & - \\
\hline \multirow[t]{3}{*}{ Culloty et al. (2004) } & $\begin{array}{l}1 \text { selected stock (S) and } 4 \\
\text { stocks from parasite-free } \\
\text { area }(\mathrm{I}) ; 700 \text { oysters, } 70 \\
\text { oysters per bag; lower } \\
\text { shore, oyster bags on } \\
\text { trestles } 40 \mathrm{~cm} \text { off bed; } \\
\text { exposed only at spring } \\
\text { tide; } 30 \text { oysters of each } \\
\text { months. } 7.7-17.6^{\circ} \mathrm{C} \text {. Site } 1\end{array}$ & $\begin{array}{c}\text { mean } \\
\text { weight } \\
57-67 \mathrm{~g}\end{array}$ & $22 \mathrm{mo}$ & $\begin{array}{l}\text { heart } \\
\text { imprint }\end{array}$ & $\begin{array}{c}20 \%, 44 \%, \\
86 \% \text { after } 6,12 \\
\text { or } 19 \text { mo }(\mathrm{S}) ; \\
5-16 \%, 38- \\
73 \%, 96-100 \% \\
\text { after } 6,12 \text { or } \\
19 \text { mo (I) }\end{array}$ & $\begin{array}{c}18 \% \text { after } 6 \mathrm{mo}, \\
25 \% \text { after } 12 \mathrm{mo}, \\
50 \% \text { after } 19 \text { mo } \\
(\mathrm{S}) ; 4-79 \% \text { after } 6 \\
\text { mo, } 77-100 \% \text { after } \\
12 \text { mo, } 50-100 \% \\
\text { after } 19 \text { mo (I) }\end{array}$ & $\begin{array}{l}\text { 3-6 mo before } \\
\text { first infections } \\
\text { (I); selected } \\
\text { stock infected } \\
\text { at beginning } \\
\text { of experiment }\end{array}$ & $\begin{array}{c}0-14 \% \\
\text { after } 6 \\
\text { mo; } 7- \\
63 \% \text { after } \\
12 \text { mo; } 0- \\
33 \% \text { after } \\
19 \text { mo of } \\
+++\end{array}$ & - \\
\hline & $\begin{array}{c}1 \text { selected stock }(\mathrm{S}), 1 \\
\text { stock from contaminated } \\
\text { area }(\mathrm{C}) \text { and } 4 \text { stocks from } \\
\text { parasite-free area }(\mathrm{I}) ; 700 \\
\text { oysters, } 70 \text { oysters per bag; } \\
\text { oyster bags on trestles; } \\
\text { continually covered; } 30 \\
\text { oysters of each stock tested } \\
\text { every } 3 \text { months. } 3.1- \\
20.4^{\circ} \mathrm{C} \text {. Site } 2\end{array}$ & $\begin{array}{c}\text { mean } \\
\text { weight } \\
57-67 \mathrm{~g}\end{array}$ & $12 \mathrm{mo}$ & $\begin{array}{l}\text { heart } \\
\text { imprint }\end{array}$ & $\begin{array}{c}44 \% \text { or } 84 \% \\
\text { after } 6 \text { or } 12 \\
\text { mo (S); } 40 \% \text { or } \\
82 \% \text { after } 6 \text { or } \\
12 \text { mo (C); } 70- \\
98 \% \text { or } 100 \% \\
\text { after } 6 \text { or } 12 \\
\text { mo (I) }\end{array}$ & $\begin{array}{l}41 \% \text { or } 55 \% \text { after } \\
6 \text { or } 12 \text { mo }(\mathrm{S}) ; \\
77 \% \text { or } 8 \% \text { after } 6 \\
12 \text { mo }(\mathrm{C}) ; 63- \\
100 \% \text { or } 22 \% \\
\text { after } 6 \text { or } 12 \text { mo } \\
\text { (I) }\end{array}$ & $\begin{array}{l}\text { 3-6 mo before } \\
\text { first infections } \\
\text { (I and C); } \\
\text { selected stock } \\
\text { infected at } \\
\text { beginning of } \\
\text { experiment }\end{array}$ & $\begin{array}{c}0-30 \% \\
\text { after } 6 \\
\text { mo; } 0-9 \% \\
12 \\
\text { mo of } \\
+++\end{array}$ & \\
\hline & $\begin{array}{c}1 \text { selected stock }(\mathrm{S}), 1 \\
\text { stock from contaminated } \\
\text { area }(\mathrm{C}) \text { and } 4 \text { stocks from } \\
\text { parasite-free area }(\mathrm{I}) ; 700 \\
\text { oysters, } 70 \text { oysters per bag; } \\
\text { oyster bags on trestles; } \\
\text { continually covered; } 30 \\
\text { oysters of each stock tested } \\
\text { every } 3 \text { months. } 9.9- \\
16.3^{\circ} \mathrm{C} \text {. Site } 3\end{array}$ & $\begin{array}{c}\text { mean } \\
\text { weight } \\
57-67 \mathrm{~g}\end{array}$ & $16 \mathrm{mo}$ & $\begin{array}{l}\text { heart } \\
\text { imprint }\end{array}$ & $\begin{array}{c}12 \%, 72 \% \text { or } \\
78 \% \text { after } 6,12 \\
\text { or } 16 \text { mo }(\mathrm{S}) ; \\
56 \%, 98 \% \text { or } \\
56 \%, 98 \% \text { or } \\
12 \text { or } 16 \text { mo } \\
(\mathrm{C}) ; 12-50 \%, \\
38-96 \% \text { or } 94- \\
100 \% \text { after } 6, \\
12 \text { or } 16 \text { mo (I) }\end{array}$ & $\begin{array}{c}14 \%, 6 \% \text { or } 28 \% \\
\text { after } 6,12 \text { or } 16 \\
\text { mo (S); } 29 \% \text { or } \\
14 \% \text { after } 6 \text { or } 12 \\
14 \% \text { after } 6 \text { or } 12 \\
\text { mo (C); } 0-12 \%, 0- \\
\text { after } 6,12 \text { or } 16 \\
\text { mo (I) }\end{array}$ & $\begin{array}{l}3 \text { mo before } \\
\text { first infections } \\
\text { (I and C); } \\
\text { selected stock } \\
\text { selected stock } \\
\text { infected at } \\
\text { experiment }\end{array}$ & $\begin{array}{c}\text { most } \\
\text { infections } \\
\text { observed } \\
\text { were light } \\
\text { were light }\end{array}$ & - \\
\hline
\end{tabular}


Annex 1. Continued.

\begin{tabular}{|c|c|c|c|c|c|c|c|c|c|}
\hline \multirow[t]{2}{*}{ Reference } & \multicolumn{3}{|c|}{$\begin{array}{l}\text { Technical information } \\
\end{array}$} & \multirow[b]{2}{*}{$\begin{array}{l}\text { Diagnostic } \\
\text { method }\end{array}$} & \multirow[b]{2}{*}{$\%$ mortality } & \multicolumn{4}{|c|}{ Results } \\
\hline & $N$ tested oysters & $\begin{array}{c}\text { Age } \\
\text { tested } \\
\text { oysters }\end{array}$ & Duration & & & $\begin{array}{l}\text { \% parasite } \\
\text { detection }\end{array}$ & $\begin{array}{c}\text { Time before } \\
\text { first } \\
\text { mortalities }\end{array}$ & $\begin{array}{l}\text { Level of } \\
\text { observed } \\
\text { infection }\end{array}$ & $\begin{array}{l}\text { Relation } \\
\text { with } \\
\text { age/size }\end{array}$ \\
\hline \multirow[t]{4}{*}{ Lynch et al. (2005) } & $\begin{array}{l}1000 \text { oysters deployed in } \\
\text { two different sites; stock } \\
\text { from parasite-free area; } \\
200 \text { oysters per bag; bags } \\
\text { placed intertidally on } \\
\text { trestles } 40 \mathrm{~cm} \text { off bed; } 60 \\
\text { oysters tested every } 2 \mathrm{~s} \\
\text { months }\end{array}$ & $1 \mathrm{mo}$ old & $6 \mathrm{mo}$ & $\begin{array}{c}\text { heart } \\
\text { mprint } \\
\text { and PCR }\end{array}$ & - & $\begin{array}{c}2-3 \% \\
\text { imprint) or 0-7\% } \\
\text { (PCR) after 4 mo; } \\
9 \% \text { (heart imprint) } \\
\text { or 3-9\% (PCR) } \\
\text { after 6 mo }\end{array}$ & $\begin{array}{l}2-4 \text { mo before } \\
\text { first infections } \\
\text { depending on } \\
\text { the site }\end{array}$ & $\begin{array}{c}+ \text { until } 4 \\
\text { mo, }++ \\
\text { after } 6 \text { mo }\end{array}$ & $\begin{array}{c}\text { older } \\
\text { oysters } \\
\text { with higher } \\
\text { prevalence } \\
\text { of infection } \\
\text { and higher } \\
\text { intensity of } \\
\text { infection }\end{array}$ \\
\hline & $\begin{array}{l}200 \text { oysters deployed in } \\
\text { one site; stock from } \\
\text { contaminated area; } 200 \\
\text { oysters per bag; bags } \\
\text { placed intertidally on } \\
\text { trestles } 40 \mathrm{~cm} \text { off bed; } 60 \\
\text { oysters tested every } 2 \\
\text { months }\end{array}$ & $2-3$ mo old & $6 \mathrm{mo}$ & $\begin{array}{c}\text { heart } \\
\text { imprint } \\
\text { and PCR }\end{array}$ & - & $\begin{array}{c}5 \% \text { (heart imprint) } \\
\text { or 10-17\% (PCR) } \\
\text { after } 4 \text { mo; 6\% } \\
\text { (heart imprint) or } \\
0-12 \% \text { (PCR) after } \\
6 \text { mo }\end{array}$ & $\begin{array}{l}\text { initial sample } \\
\text { with low } \\
\text { frequency of } \\
\text { the parasite (0-) } \\
6 \%)\end{array}$ & + & \\
\hline & $\begin{array}{l}1000 \text { oysters deployed in } \\
\text { two different sites; } 1 \text { stock } \\
\text { from parasite-free area (I) } \\
\text { and } 1 \text { stock from } \\
\text { contaminated area (C); } 200\end{array}$ & 18 mo old & $6 \mathrm{mo}$ & $\begin{array}{c}\text { heart } \\
\text { imprint } \\
\text { and PCR }\end{array}$ & - & $\begin{array}{c}5-14 \% \text { (heart } \\
\text { imprint) or 6-54\% } \\
\text { (PCR) after } 6 \text { mo } \\
\text { (I); } 7-26 \% \text { (heart } \\
\text { imprint) or 14- }\end{array}$ & $\begin{array}{l}2-4 \text { mo before } \\
\text { first infections }\end{array}$ & $\begin{array}{c}+,++ \\
+++\end{array}$ & \\
\hline & $\begin{array}{l}\text { oysters per bag; bags } \\
\text { placed intertidally on } \\
\text { trestles } 40 \mathrm{~cm} \text { off bed; } 60 \\
\text { oysters tested every } 2 \\
\text { months }\end{array}$ & & & & & $\begin{array}{c}50 \%(\text { PCR) after } 6 \\
\text { mo (C) }\end{array}$ & & & \\
\hline
\end{tabular}

-: missing information or result; + : light infection, ++ : moderate infection, +++ : heavy infection. 
Annex 2. Cohabitation experiment without injection of the parasite (source oysters come from a contaminated area)

\begin{tabular}{|c|c|c|c|c|c|c|c|c|c|}
\hline \multirow[t]{2}{*}{ Reference } & \multicolumn{6}{|c|}{ Technical information } & \multicolumn{3}{|c|}{ Results } \\
\hline & $\begin{array}{c}N \text { source } \\
\text { oysters } \\
\text { (initial } \\
\text { prevalence) }\end{array}$ & $\begin{array}{c}N \text { tested } \\
\text { oysters } \\
\text { (initial } \\
\text { prevalence) }\end{array}$ & $\begin{array}{l}\text { Experimental } \\
\text { conditions }\end{array}$ & Age & Duration & $\begin{array}{l}\text { Diagnostic } \\
\text { method }\end{array}$ & $\%$ mortality & $\begin{array}{l}\% \text { parasite } \\
\text { detection }\end{array}$ & $\begin{array}{l}\text { Time before } \\
\text { first } \\
\text { mortalities }\end{array}$ \\
\hline Elston et al. (1986) & $\begin{array}{c}55 \\
\text { (unknown) }\end{array}$ & 30 (zero) & Unknown & Unknown & $9 \mathrm{mo}$ & histology & $100 \%$ & $83 \%$ & 3-4 months \\
\hline Elston et al. (1987) & $\begin{array}{c}58 \text { (at least } \\
30 \% \text { ) }\end{array}$ & 58 (zero) & $\begin{array}{l}50-\mathrm{L} \text { tank, } \\
\text { flow of } \\
21 / \mathrm{min} \\
\text { seawater, } \\
11-17^{\circ} \mathrm{C}\end{array}$ & Unknown & $\begin{array}{l}11 \mathrm{mo} \\
11 \mathrm{mo}\end{array}$ & histology & $\begin{array}{c}26 \% \\
\text { (source), } \\
98 \% \text { (tested) } \\
\text { at the end of } \\
\text { experiment }\end{array}$ & $\begin{array}{c}12 \% \text { (source), } \\
12 \% \text { (source), } \\
\text { the end of } \\
\text { experiment }\end{array}$ & $\begin{array}{c}4 \text { weeks }(<10 \%) \\
\text { until week } \\
28)\end{array}$ \\
\hline Martin et al. (1993) & $\begin{array}{l}150(40- \\
50 \%) \text { per } \\
\text { batch }\end{array}$ & $\begin{array}{c}2 \text { batches } \\
\text { (control } \\
\text { and } \\
\text { selected); } \\
250 \text { per } \\
\text { batch (0\% } \\
\text { selected; } \\
8 \% \\
\text { control) }\end{array}$ & $\begin{array}{c}15-18^{\circ} \mathrm{C} ; \text { fed } \\
\text { with } 4.10^{9} \\
\text { cells } / \mathrm{h} / 1001 \\
\text { tank; } \\
\text { system; } \\
\text { water } \\
\text { renewed } \\
\text { during } 1 \mathrm{~h} \\
\text { every } 24 \mathrm{~h}\end{array}$ & $21 \mathrm{mo}$ old & $7 \mathrm{mo}$ & $\begin{array}{l}\text { heart and } \\
\text { digestive } \\
\text { gland } \\
\text { imprint }\end{array}$ & $\begin{array}{c}30 \% \\
\text { (control); } \\
10 \% \\
\text { (selected) }\end{array}$ & $\begin{array}{c}50 \% \text { (control) } \\
44 \% \\
\text { (selected) after } 7 \\
\text { months in } \\
\text { surviving }\end{array}$ & $\begin{array}{l}\text { week } 2 \text { for } \\
\text { selected } \\
(<5 \% \text { until } \\
\text { week 17); } \\
\text { week } 5 \text { for } \\
\text { control } \\
(<10 \% \text { until } \\
\text { week 20) }\end{array}$ \\
\hline Culloty et. (1999) & $87(25 \%)$ & $\begin{array}{c}150 \\
\text { (parasite- } \\
\text { free area) }\end{array}$ & $\begin{array}{c}500 \mathrm{~L} \text { static } \\
\text { tank, aerated, } \\
\text { sea water } \\
\text { changed } 3 \\
\text { times a } \\
\text { week, } 8- \\
15^{\circ} \mathrm{C} \text {, daily } \\
\text { food }\end{array}$ & Unknown & $6 \mathrm{mo}$ & $\begin{array}{l}\text { heart } \\
\text { imprint }\end{array}$ & $\begin{array}{c}91.6 \% \\
\text { (source } \\
\text { oysters); } \\
19.5 \% \text { (tested } \\
\text { oysters) }\end{array}$ & $\begin{array}{c}66.7 \% \text { (source } \\
\text { oysters); } 46.6 \% \\
\text { (tested oysters) } \\
\text { at the end of } 6 \\
\text { months }\end{array}$ & - \\
\hline
\end{tabular}

: missing information or result. 
Annex 3. Cohabitation experiment with injection of the parasite (source oysters injected with Bonamia ostreae).

\begin{tabular}{|c|c|c|c|c|c|c|c|c|c|c|}
\hline \multirow[t]{2}{*}{ Reference } & \multicolumn{6}{|c|}{ Technical information } & \multicolumn{4}{|c|}{ Results } \\
\hline & $\begin{array}{l}N \text { source } \\
\text { oysters } \\
\text { (Bonamia } \\
\text { injected) }\end{array}$ & $\begin{array}{c}N \text { tested } \\
\text { oysters } \\
\text { (initial } \\
\text { prevalence) }\end{array}$ & $\begin{array}{l}\text { Experimental } \\
\text { conditions }\end{array}$ & Age & Duration & $\begin{array}{c}\text { Diagnostic } \\
\text { method }\end{array}$ & $\begin{array}{c}\% \\
\text { mortality }\end{array}$ & $\begin{array}{l}\% \text { parasite } \\
\text { detection }\end{array}$ & $\begin{array}{c}\text { Time } \\
\text { before first } \\
\text { mortalities }\end{array}$ & $\begin{array}{l}\text { Level of } \\
\text { observed } \\
\text { infection }\end{array}$ \\
\hline $\begin{array}{c}\text { Culloty et al. } \\
\text { (1999) }\end{array}$ & $\begin{array}{l}100(5 \times \\
10^{6} \text { cells } \\
\text { injected in } \\
\text { each } \\
\text { oyster })\end{array}$ & 150 (zero) & $\begin{array}{c}500-\mathrm{L} \text { static tank, } \\
\text { aerated, sea water } \\
\text { changed } 3 \text { times a } \\
\text { week, } 8-15{ }^{\circ} \mathrm{C} \text {, daily } \\
\text { food }\end{array}$ & Unknown & $6 \mathrm{mo}$ & $\begin{array}{l}\text { heart } \\
\text { imprint }\end{array}$ & $\begin{array}{c}53.3 \% \\
\text { (source } \\
32 \% \\
\text { (tested } \\
\text { oysters) }\end{array}$ & $\begin{array}{c}31.2 \% \text { (source) } \\
\text { and } 12.5 \% \\
\text { moribund } \\
\text { oysters; } 80.4 \% \\
\text { (source) and } \\
22.1 \% \text { (tested) } \\
\text { in the surviving } \\
\text { oysters }\end{array}$ & - & $\begin{array}{l}- \\
-\end{array}$ \\
\hline \multirow[t]{2}{*}{ This study } & $\begin{array}{l}220(1 \times \\
10^{6} \text { cells } \\
\text { injected in } \\
\text { each of } \\
160 \\
\text { oysters })\end{array}$ & $\begin{array}{c}500 \\
\text { Family } 1\end{array}$ & $\begin{array}{c}5 \times 150 \text {-L tanks; each } \\
\text { tank containing } 100 \\
\text { tested oysters and } \\
44 \text { source oysters } \\
(32 \text { injected); water } \\
\text { flow } 150 \mathrm{~L} \mathrm{~h}^{-1} ; \\
\text { daily food; sea } \\
\text { water changed once } \\
\text { a week }\end{array}$ & $\begin{array}{c}20 \mathrm{mo} \\
\text { old }\end{array}$ & $6 \mathrm{mo}$ & $\begin{array}{l}\text { heart t } \\
\text { imprint }\end{array}$ & $\begin{array}{c}58 \% \\
\text { (source); } \\
9.4 \% \\
\text { (tested) }\end{array}$ & $\begin{array}{l}67.5 \% \text { in the } \\
\text { moribund } \\
\text { oysters (tested) }\end{array}$ & $\begin{array}{c}4 \text { months } \\
4 \text { before first } \\
\text { infections } \\
\text { (tested) }\end{array}$ & $\begin{array}{c}33 \% \text { of }+, 26 \% \\
\text { of }++ \text { and } 9 \% \text { of } \\
+++ \text { after } 6 \text { mo } \\
\text { in the dead } \\
\text { oysters (tested) }\end{array}$ \\
\hline & $\begin{array}{c}220(1 \times \\
10^{6} \text { cells } \\
\text { injected in } \\
\text { each of } \\
170 \\
\text { oysters })\end{array}$ & $\begin{array}{c}550 \\
\text { Family } 2\end{array}$ & $\begin{array}{c}5 \times 150 \text {-L tanks; each } \\
\text { tank containing } 110 \\
\text { tested oysters and } \\
44 \text { source oysters } \\
(34 \text { injected }) \text {; water } \\
\text { flow } 150 \mathrm{~L} \mathrm{~h}^{-1} ; \\
\text { daily food; sea } \\
\text { water changed once } \\
\text { a week }\end{array}$ & 8 mo old & $6 \mathrm{mo}$ & $\begin{array}{l}\text { heart } \\
\text { imprint }\end{array}$ & $\begin{array}{c}58 \% \\
\text { (source) } \\
19.1 \% \\
\text { (tested) }\end{array}$ & $\begin{array}{c}89.5 \% \text { in the } \\
\text { moribund } \\
\text { oysters (tested); } \\
11 \% \text { in the } \\
\text { surviving } \\
\text { oysters (tested) }\end{array}$ & $\begin{array}{l}4 \text { months } \\
\text { before first } \\
\text { infections } \\
\text { (tested) }\end{array}$ & $\begin{array}{c}18 \% \text { of }+, 25 \% \\
\text { of }++ \text { and } 46 \% \\
\text { of }+++ \text { after } 6 \\
\text { mo in the dead } \\
\text { oysters (tested); } 8 \\
8 \% \text { of }+ \text { and } 3 \% \\
\text { of }++ \text { in the } \\
\text { surviving } \\
\text { oysters (tested) }\end{array}$ \\
\hline
\end{tabular}

-: missing information or result; + : light infection, ++ : moderate infection, +++ : heavy infection. 
Annex 4. Experimental infection by injection of purified parasite.

\begin{tabular}{|c|c|c|c|c|c|c|c|c|c|c|c|}
\hline \multirow[t]{2}{*}{ Reference } & \multicolumn{7}{|c|}{ Technical information } & \multicolumn{4}{|c|}{ Results } \\
\hline & $N$ oysters & $\begin{array}{l}\text { Experimental } \\
\text { conditions }\end{array}$ & $\begin{array}{l}\text { Inoculation } \\
\text { location }\end{array}$ & $\begin{array}{c}N \\
\text { Bonamia } \\
\text { injected }\end{array}$ & $\overline{\text { Age }}$ & Duration & $\begin{array}{l}\text { Diagnostic } \\
\text { method }\end{array}$ & $\begin{array}{c}\% \\
\text { mortality }\end{array}$ & $\begin{array}{l}\% \text { parasite } \\
\text { detection }\end{array}$ & $\begin{array}{c}\text { Time } \\
\text { before } \\
\text { first } \\
\text { mortalities }\end{array}$ & $\begin{array}{l}\text { Level of } \\
\text { observed } \\
\text { infection }\end{array}$ \\
\hline $\begin{array}{l}\text { Mialhe et al. } \\
\text { (1988) }\end{array}$ & $\begin{array}{l}3 \text { batches of } \\
30 \text { oysters } \\
\text { (parasite- } \\
\text {-free area) }\end{array}$ & - & $\begin{array}{l}\text { digestive } \\
\text { gland }\end{array}$ & - & Unknown & $4 \mathrm{mo}$ & $\begin{array}{l}\text { gill tissue } \\
\text { imprint }\end{array}$ & $\begin{array}{c}100 \% \\
\text { after } 4 \text { mo } \\
\text { after } 4 \text { mo }\end{array}$ & $\begin{array}{c}50 \% \text { after } \\
2 \text { mo, } \\
100 \%\end{array}$ & $\begin{array}{l}- \\
-\end{array}$ & - \\
\hline $\begin{array}{l}\text { Martin et al. } \\
\text { (1993) }\end{array}$ & $\begin{array}{c}2 \text { batches } \\
\text { (control and } \\
\text { selected); } \\
250 \text { per } \\
\text { batch; initial } \\
\text { prevalence } \\
0 \% \\
\text { (selected) } \\
\text { and } 8 \% \\
\text { (control) }\end{array}$ & $\begin{array}{c}15-18{ }^{\circ} \mathrm{C} ; \text { fed } \\
\text { with } 4 \times 10^{9} \\
\text { cell } \mathrm{h}^{-1} 100 \mathrm{~L}^{-1} \\
\text { tank; } \\
\text { closed } \\
\text { system; } \\
\text { water } \\
\text { renewed } \\
\text { during } 1 \mathrm{~h} \\
\text { every } 24 \mathrm{~h}\end{array}$ & $\begin{array}{c}\text { heart (after } \\
\text { anaesthesia } \\
\text { with } \\
\left.\mathrm{MgCl}_{2}\right)\end{array}$ & $\begin{array}{c}50000 \\
\text { cells per } \\
\text { oyster }\end{array}$ & 21 mo old & $7 \mathrm{mo}$ & $\begin{array}{l}\text { heart and } \\
\text { digestive } \\
\text { gland } \\
\text { imprint }\end{array}$ & $\begin{array}{c}52.4 \% \\
\text { (control); } \\
28 \% \\
\text { (selected) }\end{array}$ & $\begin{array}{c}68 \% \\
\text { (control) } \\
\text { and } 51 \% \\
\text { (selected) } \\
\text { after } 7 \text { mo } \\
\text { in } \\
\text { surviving }\end{array}$ & $\begin{array}{c}\text { week } 15 \\
\text { for } \\
\text { selected } \\
<10 \% \\
\text { until week } \\
23) \text {; week } \\
1 \text { for } \\
\text { control } \\
(<10 \% \\
\text { until week 19) }\end{array}$ & \\
\hline \multirow[t]{2}{*}{$\begin{array}{l}\text { Hervio et al. } \\
\text { (1995) }\end{array}$} & 30 (zero) & $\begin{array}{l}\text { 50-L tank, digestive } \\
\text { recirculating } \\
\text { filtered sea- } \\
\text { water }(10 \mu \mathrm{m})\end{array}$ & $\begin{array}{l}10000 \\
\text { gland }\end{array}$ & 3 years & $\begin{array}{l}4 \mathrm{mo} \\
\text { old }\end{array}$ & $\begin{array}{l}\text { heart imprint } \\
4 \text { mo }\end{array}$ & $26 \%$ after & $\begin{array}{c}34 \% \text { after } \\
4 \text { mo }\end{array}$ & $\begin{array}{l}4 \text { months } \\
4 \text { mo }\end{array}$ & $\begin{array}{c}+,++ \\
\text { before } \\
\text { first } \\
\text { infections }\end{array}$ &,+++ \\
\hline & 43 (zero) & $\begin{array}{c}\text { changed } \\
\text { weekly, } 18^{\circ} \mathrm{C}\end{array}$ & & 1000000 & & & $4 \mathrm{mo}$ & $\begin{array}{c}43 \% \text { after } \\
4 \text { mo }\end{array}$ & $\begin{array}{c}69 \% \text { after } \\
\text { before }+++\end{array}$ & $\begin{array}{l}2 \text { months } \\
\text { first } \\
\text { infections }\end{array}$ &,+++ \\
\hline $\begin{array}{l}\text { Hervio et al. } \\
\text { (1995) }\end{array}$ & 100 (zero) & $\begin{array}{c}200-\mathrm{L} \text { tank, } \\
\text { recirculating } \\
\text { filtered sea- } \\
\text { water }(10 \mu \mathrm{m}) \\
\text { changed weekly, } \\
18^{\circ} \mathrm{C}\end{array}$ & $\begin{array}{l}\text { digestive } \\
\text { gland }\end{array}$ & 220000 & $\begin{array}{l}3 \text { years } \\
\text { old }\end{array}$ & $4 \mathrm{mo}$ & heart imprint & $\begin{array}{c}43 \% \text { after } \\
4 \text { mo }\end{array}$ & $\begin{array}{c}52 \% \text { after } \\
4 \text { mo }\end{array}$ & $\begin{array}{l}2 \text { months } \\
\text { before } \\
\text { first } \\
\text { infections }\end{array}$ & $\begin{array}{c}+,++ \\
+++\end{array}$ \\
\hline
\end{tabular}




\begin{tabular}{|c|c|c|c|c|c|c|c|c|c|c|c|}
\hline \multirow[t]{2}{*}{ Reference } & \multicolumn{7}{|c|}{ Technical information } & \multicolumn{4}{|c|}{ Results } \\
\hline & $N$ oysters & $\begin{array}{l}\text { Experimental } \\
\text { conditions }\end{array}$ & $\begin{array}{c}\text { Inoculation } \\
\text { location }\end{array}$ & $\begin{array}{c}N \\
\text { Bonamia } \\
\text { injected }\end{array}$ & Age & Duration & $\begin{array}{l}\text { Diagnostic } \\
\text { method }\end{array}$ & $\begin{array}{c}\% \\
\text { mortality }\end{array}$ & $\begin{array}{l}\text { \% parasite } \\
\text { detection }\end{array}$ & $\begin{array}{c}\text { Time } \\
\text { before } \\
\text { first } \\
\text { mortalities }\end{array}$ & $\begin{array}{l}\text { Level of } \\
\text { observed } \\
\text { infection }\end{array}$ \\
\hline $\begin{array}{c}\text { Hervio et al. } \\
\text { (1995) }\end{array}$ & $\begin{array}{c}4 \text { groups } \\
\text { containing } \\
\text { each } 160, \\
43,97 \text { or } 61 \\
\text { oysters ( } 2 \\
\text { different } \\
\text { locations) }\end{array}$ & $\begin{array}{c}200-\mathrm{L} \text { tank, } \\
\text { recirculating } \\
\text { filtered sea- } \\
\text { water }(10 \mu \mathrm{m}) \\
\text { changed } \\
\text { weekly, } 18^{\circ} \mathrm{C}\end{array}$ & $\begin{array}{l}\text { digestive } \\
\text { land }\end{array}$ & 100000 & $\begin{array}{c}3-4 \text { years } \\
\text { old }\end{array}$ & $6 \mathrm{mo}$ & heart imprint & $\begin{array}{c}\text { 32-79\% } \\
\text { after } 6 \\
\text { mo, } \\
\text { depending } \\
\text { on the } \\
\text { group } \\
\text { (32\% for } \\
\text { "resistant" } \\
\text { group) } \\
\text { group) }\end{array}$ & $\begin{array}{c}20-69 \% \\
\text { after 6 } \\
\text { mo, } \\
\text { depending } \\
\text { on the } \\
\text { group } \\
\text { (20\% for } \\
\text { "resistant" }\end{array}$ & $\begin{array}{l}2-4 \text { months } \\
\text { months } \\
\text { before } \\
\text { first } \\
\text { infections }\end{array}$ & $\begin{array}{c}+,++, \\
+++(14- \\
51 \% \text { of } \\
+++ \text { after } \\
6 \mathrm{mo})\end{array}$ \\
\hline \multirow[t]{2}{*}{$\begin{array}{c}\text { Culloty et al. } \\
\text { (1999) }\end{array}$} & $\begin{array}{c}180 \text { (zero); } \\
30 \text { oysters } \\
\text { tested after } \\
2 \text { weeks and } \\
\text { remaining } \\
\text { ones after } 6 \\
\text { months }\end{array}$ & $\begin{array}{c}\text { 500-L static } \\
\text { tank, aerated, } \\
\text { sea water } \\
\text { changed } 3 \\
\text { times a week, } \\
8-15^{\circ} \mathrm{C} \text {, daily } \\
\text { food }\end{array}$ & $\begin{array}{l}\text { mantle } \\
\text { cavity }\end{array}$ & 5000000 & Unknown & $6 \mathrm{mo}$ & heart imprint & $\begin{array}{c}53 \% \text { after } \\
6 \mathrm{mo}\end{array}$ & $\begin{array}{c}31.2 \% \\
6 \text { mo } \\
\text { in } \\
\text { moribund; } \\
80.4 \% \\
\text { surviving } \\
\text { oysters }\end{array}$ & - & - \\
\hline & $\begin{array}{c}19 \text { (zero); } \\
\text { hemolymph } \\
\text { tested after } \\
7 \text { weeks; } \\
\text { remaining } \\
\text { ones after } 6 \\
\text { months }\end{array}$ & $\begin{array}{c}\text { 75-L tank, } \\
\text { aerated, daily } \\
\text { food, filtered } \\
\text { and UV } \\
\text { treated sea } \\
\text { water }\end{array}$ & $\begin{array}{l}\text { mantle } \\
\text { cavity }\end{array}$ & 4150000 & Unknown & $6 \mathrm{mo}$ & $\begin{array}{l}\text { hemolymph } \\
\text { imprint and } \\
\text { histology }\end{array}$ & $\begin{array}{c}5.5 \% \text { after } \\
6 \mathrm{mo}\end{array}$ & $\begin{array}{c}100 \% \\
\text { after } 6 \text { mo } \\
\text { in } \\
\text { moribund; } \\
29.4 \% \text { in } \\
\text { in surviving } \\
\text { oysters }\end{array}$ & & \\
\hline
\end{tabular}

-: missing information or result; +: light infection, ++ : moderate infection, +++ : heavy infection 